\title{
The Institutional Sources of Economic Transformation: Energy Policy from the Oil Crises to Climate Change*
}

\author{
Jared J. Finnegan, Phillip Y. Lipscy, Jonas O. Meckling, Florence Metz
}

\begin{abstract}
Why are some governments more effective in promoting economic change than others? We develop a theory of the institutional sources of economic transformation. Domestic institutions condition the ability of policymakers to impose costs on consumers and producers. We argue that institutions can enable transformation through two central mechanisms: insulation and compensation. The institutional sources of transformation vary across policy types-whether policies impose costs primarily on consumers (demand-side policies) or on producers (supply-side policies). Proportional electoral rules and strong welfare states facilitate demand-side policies, whereas autonomous bureaucracies and corporatist interest intermediation facilitate supply-side policies. We test our theory by leveraging the 1973 oil crisis, an exogenous shock that compelled policymakers to simultaneously pursue transformational change across OECD countries. Panel analysis, case studies, and discourse network analysis support our hypotheses. The findings offer important lessons for contemporary climate change policy and low-carbon transitions.

\footnotetext{
* Jared J. Finnegan, Department of Environmental Science, Policy, and Management, University of California, Berkeley, 130 Mulford Hall \#3114, Berkeley, CA, 94720 (jjfinnegan@berkeley.edu).

Phillip Y. Lipscy Associate Professor at the Department of Political Science and Munk School of Global Affairs and Public Policy, University of Toronto, 1 Devonshire Place, Toronto, ON M5S 3K7, Canada (phillip.lipscy@utoronto.ca).

Jonas O. Meckling, Department of Environmental Science, Policy, and Management, University of California, Berkeley, 130 Mulford Hall \#3114, Berkeley, CA, 94720 (meckling@berkeley.edu).

Florence Metz, Department of Governance and Technology for Sustainability, University of Twente, Drienerlolaan 5, NL-7522 NB Enschede (f.a.metz@utwente.nl).

For their feedback on earlier drafts of this paper, we would like to thank Jeff Colgan, Jessica F. Green, Robert O. Keohane, Tasha Fairfield, Steven K. Vogel, participants at the Comparative Politics of Climate Change policy workshops (Stanford University), and audiences at the 2020 APSA Annual Meeting and the Grantham Research Institute on Climate Change and the Environment. We thank Bill Kakenmaster, Clayton Munnings, Martina Rapp, Veronika Schick, and Samuel Trachtman for excellent research assistance. Research for this paper, and discussion at several research meetings, was made possible by generous funding from the Balzan Foundation under the terms of a prize awarded in 2017 to Professor Robert O. Keohane and administered by Princeton University and the Center for Advanced Study in the Behavioral Sciences under his supervision.
} 
Why are some governments more effective in promoting transformative economic change than others? This question has long engaged scholars across political science, sociology, and economic history. It has gained renewed urgency for advanced industrialized economies as their governments have taken on a more active role during the 2008/09 financial crisis and COVID-19 pandemic (Lipscy 2020, Hochstetler 2020). In addition, intensifying concerns over climate change have refocused attention on the role of the state in facilitating transformational change in the energy sector (Aklin and Urpelainen 2018, Stokes 2020, Ross, Hazlett, and Mahdavi 2017, Colgan, Green, and Hale 2020, Hochstetler 2020).

We define an economic transformation as a structural change that fundamentally and sustainably reconfigures economic activity. Policy-driven economic transformations often focus on enhancing growth and productivity, but they can also address externalities such as mitigating energy security vulnerabilities and climate change. A central challenge policymakers face in facilitating transformative change is opposition from economic interests that stand to lose from change (Olson 1982). Structural economic change reallocates resources across and within economic sectors, creating winners and losers. Incumbent interest groups can resist and block change through counter-mobilization, and voters can express their displeasure at the ballot box. The politics of economic transformation thus raise fundamental questions about the conditions under which policymakers can override such opposition.

We argue that governments have two general avenues through which they can adopt transformative policies that impose costs: insulation and compensation. There can be variation in the degree of insulation government policymakers enjoy from economic losers. Greater insulation reduces opportunities for losers to block transformational change (Mildenberger 2020, Jacobs 2011, Lindvall 2017). Governments can also compensate policy losers. Compensation aims to reduce the costs that incumbent groups bear as they transition to a new status quo. The goal is to render cost-bearing groups cooperative and induce them to support reform (Katzenstein 1985; Lindvall 2017; Roland 2002; Trebilcock 2014). If governments cannot rely on insulation or compensation, losers will have both the will and the ability to stymie policy reforms, increasing the likelihood of government retreat.

Transformational change is a multi-causal process. In this article, we focus on the role political institutions play in mediating distributional struggles (Steinmo, Thelen, and Longstreth 1992, Chp. 1). We develop a theory of the institutional sources of economic transformation and hypothesize that variation in institutions affects the capacity of governments to undertake major reforms. Our primary focus is advanced industrialized democracies, but the theory has implications for transformations in a wider set of countries.

We test our theory by examining policy responses of OECD countries to the 1973 oil crisis. Major structural change in energy systems is an increasingly salient, yet underexplored, type of economic transformation (Aklin and Urpelainen 2013, Keohane 2014). The abrupt and sharp increase in oil prices in 1973 constituted a common energy and economic shock across the industrialized world. During the oil crisis, governments became instantly aware of their economic 
vulnerability in the face of energy price volatility, generating a common imperative to reduce oil dependence. Countries varied, however, in the extent to which they successfully shifted their economies away from oil. This divergence in response to a common exogenous shock provides an opportunity to study how domestic institutions structure energy transitions.

To test our theory, we use a multi-method approach leveraging panel data, case studies, and discourse network analysis. First, we analyze a panel dataset of energy outcomes and institutional variables to demonstrate an empirical association between domestic political institutions and energy transition outcomes. Leveraging the 1973 oil price shock, we use panel analysis and the generalized synthetic control method to evaluate our core theoretical propositions. Second, we conduct case studies of France, Germany, and the United Kingdom to evaluate the proposed causal mechanisms related to insulation and compensation. Third, we complement the case studies with discourse network analysis, drawing on an original dataset based on contemporaneous accounts of meetings among government policymakers and interest groups. The evidence consistently supports our theoretical propositions.

The remainder of this article unfolds in four steps. First, we develop our theory on the institutional sources of insulation and compensation in the context of debates on the politics of economic transformation. We also discuss our methods. Second, we test our theory in the empirical setting of the oil price shocks of the 1970s. Third, we discuss the implications of our theory for the emerging low-carbon transition in response to climate change. Finally, we conclude by drawing out implications for research on the politics of economic change in advanced economies.

\section{Government Strategies: Insulate, Compensate, Retreat}

Economic transformation can be a long, gradual process that takes place without deliberate government intervention. However, governments sometimes face a strong impetus to facilitate or accelerate change. Some governments, such as those in East Asia, have pursued active economic intervention as a developmental strategy (Amsden 1989, Evans 1995). Major crises like economic depressions and pandemics can also reveal shortcomings of the status quo and create an impetus for government intervention. Energy and environmental crises have also produced varying degrees of intervention as governments seek to address externalities.

Government-led economic transformation inevitably imposes costs on some groups in society. Government regulations and manipulation of prices to discourage certain types of activity benefit some actors while creating a burden on others. Policy losers have a clear incentive to oppose change. Importantly, losers can be both producers and consumers. For example, in the case of climate change mitigation, fossil fuel companies are policy losers on the producer side (Colgan, Green, and Hale 2020), while household energy consumers may face the burden of higher energy prices. The politics of economic transformation entails significant distributional conflict as policy losers mobilize to block change (Olson 1982).

We argue that governments can overcome opposition from losers through two distinct mechanisms: insulation and compensation. In some countries, losers may have limited access to 
the policymaking process, giving decisionmakers relative flexibility to discount their opposition. The ability of losers to block reforms by exercising veto power varies meaningfully across political systems (Jacobs 2011; Lindvall 2017). Politicians can also be insulated if they are secure in office due to low electoral competition and accountability (Garrett 1993), which reduces the likelihood of being voted out from office for imposing diffuse costs on voters.

The second strategy is to compensate policy losers. Compensation aims to reduce the costs that incumbent groups face as they transition to the new status quo. Compensation can take a variety of forms, including direct financial payments, targeted tax cuts, policy exemptions, phased implementation, and grandfathering. The goal is to render cost-bearing groups cooperative and induce them to support reform (Lindvall 2017; Roland 2002; Trebilcock 2014). Scholars have demonstrated how compensation plays a key role in easing the costs of adjustment during a variety of cases of major policy change, including labor market reform (Knotz and Lindvall 2015), trade liberalization (Katzenstein 1985; Rodrik 1998), and climate change (Finnegan 2019; Kono 2019).

Compensatory policies raise nontrivial challenges. Compensation based on redistributive transfers requires adequate fiscal resources to offset costs (Roland 2002). Additionally, compensation can weaken the objective of reform (dilution costs), take too much time and coordination to negotiate (transaction costs), or upset the government's constituents (audience costs) (Lindvall 2017). Compensation also often involves commitment problems (Lindvall 2017; Roland 2002): policy losers may oppose reform if they believe promises of future compensation are not credible.

If policymakers are unable to rely on either insulation or compensation, losers will have both the will and ability to block transformative change, forcing governments to retreat from their policy goals. While change may still occur due to economic and social forces, the role of government as a facilitator will be limited.

Figure 1 visualizes our theoretical expectations. Transformative change can occur through two mechanisms: insulation or compensation. If government decisionmakers are insulated, reforms can be implemented over the objections of losers. When insulation is unavailable or limited, compensation can offer an alternative mechanism. The two mechanisms should both produce successful reforms, though we expect variation in the nature of the policy process and disposition of losers. If both insulation and compensation are unavailable, losers will have both the ability and incentive to stymie reforms, resulting in retreat.

Figure 1 presents our theory in the simplest terms for the purpose of exposition, but the framework is flexible and easily adapted to a more complex interplay of insulation and compensation. Insulation and compensation can exist on a continuum and vary by specific circumstances, sectors, and policy levers. Governments may pursue a blended strategy or take advantage of insulation and compensation selectively. Factors like norms, historical precedent, and issue linkage may compel governments to pursue a degree of compensation even if they are insulated. Our core theoretical prediction is that there should be a meaningful difference in policy outcomes between countries where mechanisms of insulation and/or compensation are available and those where both mechanisms are absent. 
Figure 1: Theoretical Expectations

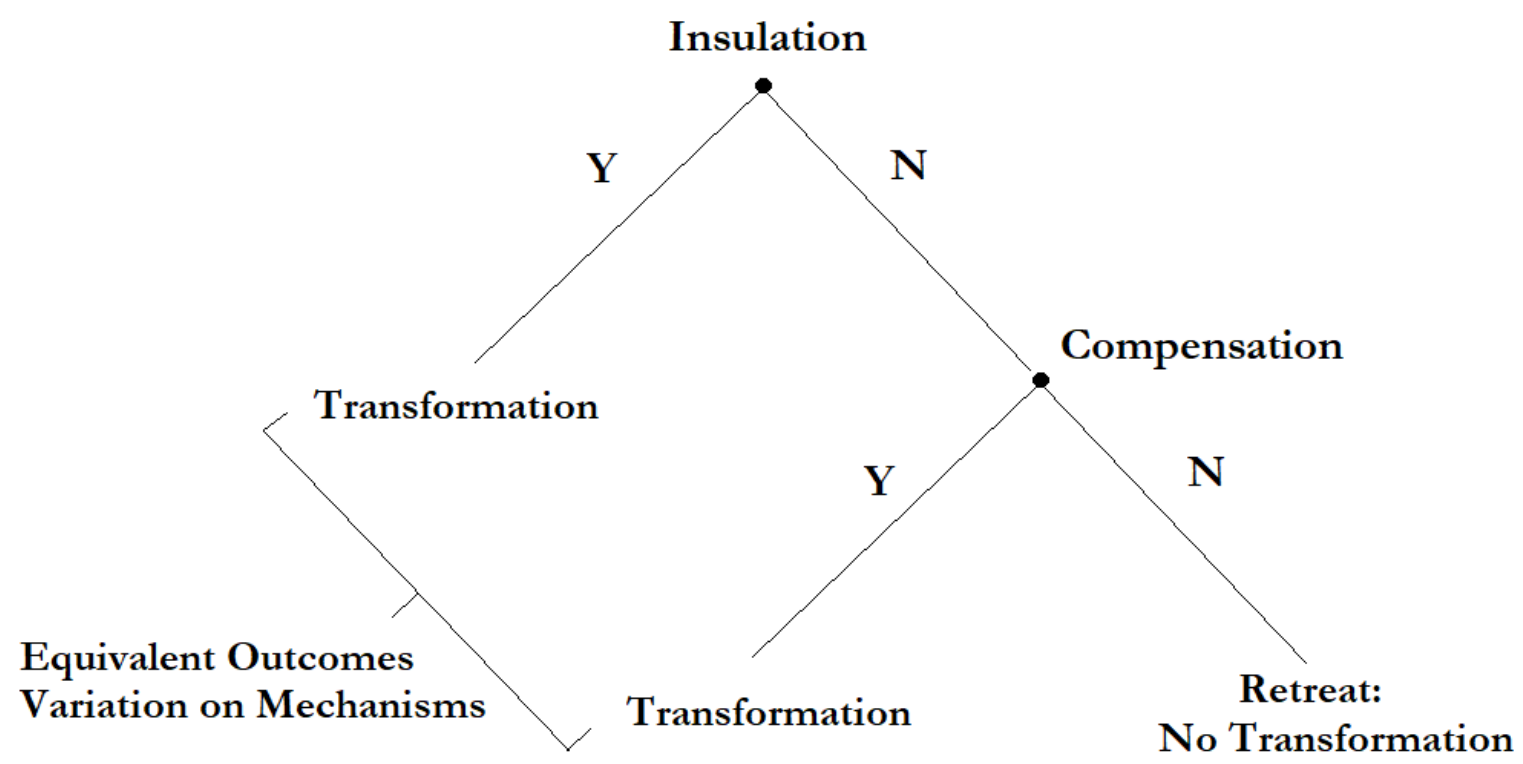

We refer to policies imposing costs on consumers as demand-side policies, and policies imposing costs on producers as supply-side policies. Both types of policies have been used across a variety of economic transformations. Supply-side policies are central in industrial policy: to alter the sectoral composition of the economy, governments impose costs on some producers with the goal of upgrading and phasing out obsolete industries (Johnson 1982). Demand-side policies also matter. For example, the developmental states of East Asian economies required "forced savings" from consumers to finance industrial development, thus levying a quasi tax (Krieckhaus 2002). Similarly, countries today are leveraging carbon taxes on consumers to promote energy efficient behavior and low-carbon energy sources (Rabe, Kraft, and Kamieniecki 2018).

\section{Domestic Institutions and Economic Transformation}

To test our theory, we examine domestic institutions as a source of variation in the availability of insulation and compensatory mechanisms for governments. Institutions mediate distributional struggles, providing opportunities for and obstacles to policy change (Steinmo, Thelen, and Longstreth 1992, Chp. 1). A rich scholarship has shown how domestic institutions influence, among other things, industrial policy (Katzenstein 1985), labor market regulation (Martin and Swank 2012), privatization (Schmidt 1996), consumer prices (Rogowski and Kayser 2002), taxation (Scheve and Stasavage 2010, Steinmo 1989), and varieties of capitalism (Hall and 
Soskice 2001). By applying and extending this literature, we develop a typology of domestic institutional sources of insulation and compensation for demand-side and supply-side policies.

\section{The Institutional Sources of Insulation}

Demand-side policy measures-like gasoline and carbon taxes-impose costs to shift consumption patterns in a direction supportive of economic transformation. In liberal democracies, consumers who bear the cost of these measures can express their objections at the ballot box. Two factors should influence how insulated policymakers are from such electoral backlash. The first is electoral competition, or the probability that the largest party in the legislature will lose its seats plurality during the next election (Kayser and Lindstädt 2015). When governments enjoy low levels of competition, marginal changes in vote shares are less likely to remove them from power. The second is electoral accountability, or the ability of voters to identify political actors responsible for policy changes and sanction them accordingly (Powell and Whitten 1993). When accountability is low, it is difficult for voters to identify responsible parties and remove them from office.

Electoral rules shape both competition and accountability. Because seats-votes elasticities tend to be lower under proportional representation (PR), governments elected under these rules tend to enjoy systematically lower levels of competition (Kayser and Lindstädt 2015; Persson and Tabellini 1999; Rogowski and Kayser 2002). At the same time, PR tends to produce multi-party coalition governments, while majoritarian rules tend to produce single-party ones. Given their higher clarity of responsibility, voters should find it easier to punish single-party governments compared to multi-party ones (Persson, Roland, and Tabellini 2007; Powell and Whitten 1993). The overall result is that governments should tend to experience higher levels of electoral insulation under proportional than majoritarian rules, and therefore less fear from backlash by consumers bearing costs. Indeed, previous studies find evidence that PR is associated with higher consumer prices generally (Rogowski and Kayser 2002), as well as higher policy costs pushed on consumers in the case of climate and energy reforms (Finnegan 2019; Lipscy 2018).

H1: PR rules facilitate demand-side reform by insulating governments from electoral backlash.

When considering structural reforms, governments fear not only pushback from voters but also organized producer groups. The sources of insulation from producers differ, however, from those of insulation from consumers. Organized interest groups typically exert influence by lobbying policymakers directly. Delegation of authority to strong, autonomous bureaucracies can diminish the ability of organized producers to influence policymaking processes. Bureaucratic autonomy exists when agencies can take "sustained patterns of action consistent with their own wishes, patterns that will not be checked or reversed by elected authorities, organized interests, or courts" (Carpenter 20011,144). 
The literature on economic development has long emphasized the importance of autonomous bureaucratic agencies in implementing structural economic change in countries such as Japan and the Asian tiger states (Amsden 1989, Johnson 1982, Wade 1990, Woo-Cumings 1999). Although relationships between bureaucrats and private sector firms were important channels for information - resulting in 'embedded autonomy' for state agencies (Evans 1995) governments' ability to reallocate resources within and across sectors relied on strong bureaucracies relatively insulated from producer interests.

We generalize this insight. In countries where state agencies enjoy relative autonomy, policymakers should be better insulated from policy losers among producer groups. As a result, we expect these governments to have higher capacity to undertake supply-side reforms.

H2: Autonomous bureaucracies facilitate supply-side reforms by insulating policymaking from producers.

\section{The Institutional Sources of Compensation}

We turn next to institutions that facilitate the compensation of consumers and producers. On the demand-side, adjustment costs are diffuse, and compensatory mechanisms must be equally broad based. Social welfare state institutions can compensate individuals directly for higher costs incurred through adjustment measures and cushion associated economic dislocations. By easing the costs of adjustment to the new status quo, a robust welfare state should reduce political resistance to reform amongst diffuse consumers.

The case of trade is illuminating. There is strong evidence that countries with high social spending are also more open to international trade (which, while often net beneficial for an economy, harms some people) (Katzenstein 1985; Rodrik 1998). Moreover, individuals are more likely to support trade liberalization when social spending is high (Hays, Ehrlich, and Peinhardt 2005). Similarly, pro-trade politicians representing exporters are more likely to vote for trade adjustment assistance (Rickard 2015), while politicians from districts with generous unemployment benefits are more likely to vote for free trade (Kono 2011). Notably, the latter relationship also holds for climate change mitigation policy (Kono 2019).

Countries with well-developed welfare state institutions should be better able to compensate for the economic burden of adjustment measures that impose costs on households through, for example, direct financial transfers, unemployment insurance, vocational training, and pensions. What is more, in countries with a long history of welfare state institutions and a 'habit' of compensation, compensatory commitments are more likely to be seen as credible by voters, and therefore more likely to be trusted (Campbell 2012). The result is that politicians in these countries should have greater capacity to overcome opposition from policy losers on the demand side.

H3: Welfare states facilitate demand-side reform by enabling governments to compensate consumers. 
In the case of producers, we expect institutions that structure the relationship between the state and industry to affect the feasibility of compensatory measures. Under corporatist forms of interest group intermediation, peak associations for business and labor are granted privileged access to pre-legislative policy design. These types of fora should increase the capacity for compensatory bargaining between government and producers. First, negotiations take place between few, highly organized actors. Second, decades of repeated, face-to-face interactions generate trust. Specifically, producers come to trust that the government will uphold its commitment to future compensation and the government trusts that producers will uphold their commitment to support the reform. Small group size, repeated interactions, and trust can reduce the transaction costs associated with compensatory bargaining (Lindvall 2017; Warren and Mansbridge 2016). Lastly, because negotiations are often held in private, audience costs are reduced (Warren and Mansbridge 2016).

Existing studies offer evidence that corporatism facilitates governments in reaching compensatory bargains with producers. Katzenenstein___(1985) points to corporatism as the key institution that enables governments in small European states to adopt industrial policy reforms by compensating business and labor. Similarly, corporatism facilitated the compensation of labor unions for wage restraint during times of high inflation. More recently, there is evidence that corporatism facilitates climate change policy by enabling governments to compensate cost-bearing industry and workers (Finnegan 2019).

H4: Corporatism facilitates supply-side reforms by enabling governments to compensate producers.

If countries possess neither institutional sources for insulation nor for compensation, we expect policymakers will face difficulty in facilitating economic transformations. Incumbent producers will be able to block ambitious supply-side policies. Politicians will shy away from demand-side measures for fear of punishment at the ballot box. Hence, while the presence of insulation or compensatory institutions will be associated with transformative change, the absence of both will be associated with retreat.

\section{Research Design: The 1970s Oil Price Shocks}

There is a large universe of economic transformations we could potentially examine to test our theory. Disruptive, transformational economic change has been an important feature of modern society going back to at least the industrial revolution, encompassing major shifts such as the shift from sailing to steam ships starting in the 1780s and quine transport to automobiles in the early $19^{\text {th }}$ century (Geels and Schot 2007) as well as industrial mobilization during World War II (Kennedy 1999). More recent examples include active state intervention to facilitate rapid economic growth in late-industrializing countries (Johnson 1982, Amsden 1989), shock therapy in 
post-communist transition countries (Frye 2002, Saich 2010), and the global response to major challenges like climate change and COVID-19 (Lipscy 2020, Rodrik 2014).

There are several important empirical challenges presented by these cases. Historical transformations often took place over many years and affected countries at different moments in time. This makes it tricky to control for potential temporal confounders such as technological change and learning from prior transformations. Transformations also often occurred concurrently with major institutional changes: to test our theory, it is important to focus on cases where institutions are plausibly exogenous and stable and therefore not confounded by omitted variables causing both institutional and economic change.

We test our theory by leveraging the oil crises of the 1970s. From the end of World War II until 1972, international oil prices remained stable and low (Figure 2). As a result, national energy systems underwent significant fuel switching from coal to oil, driven primarily by market forces. However, in October 1973, energy markets underwent a major disruption. The Organization of Petroleum Exporting Countries (OPEC) sharply increased the price of oil in an effort to punish Western countries for supporting Israel in the Yom Kippur War. Over the course of three months, the international price of oil quadrupled from $\$ 2.90$ nominal USD per barrel in mid-1973 to $\$ 11.65$ by the start of 1974. A second price shock hit the world in 1979 due to fears of reduced supply resulting from the Iranian Revolution, further doubling oil prices from their 1978 levels (see Figure 2).

Figure 2. Crude oil prices 1950-2000

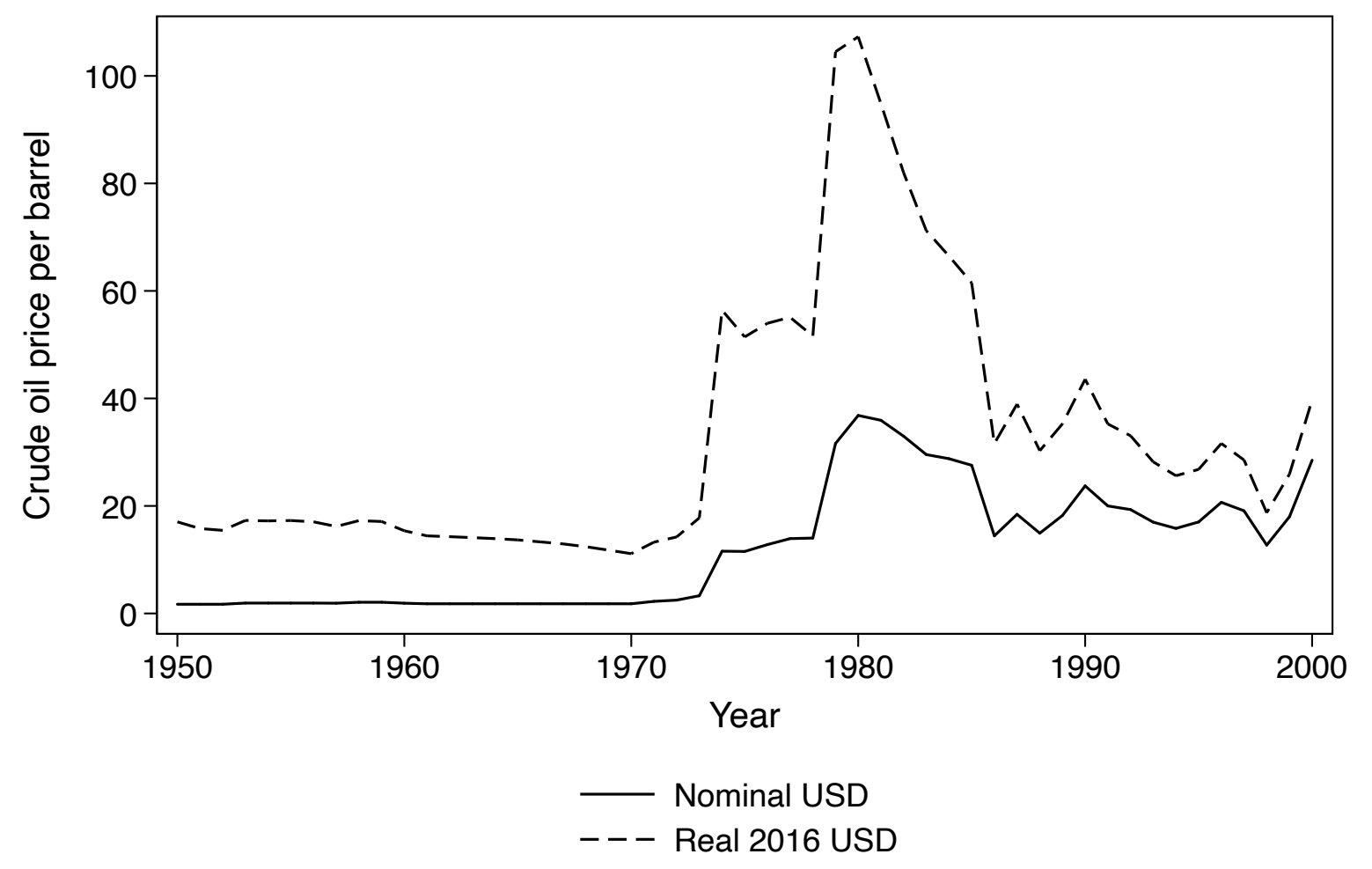


These common energy price shocks induced all advanced industrialized states to simultaneously pursue significant, state-led transformations of their economic and energy systems. In early 1974, OECD countries laid out three common goals at a meeting in Washington: diversify oil imports away from the Middle East, diversify national energy systems away from oil to other fuels, and adopt conservation measures to reduce energy consumption (Ikenberry_198_6__107_). That same year, the industrial economies founded the International Energy Agency (IEA) with the Agreement on an International Energy Programme. The treaty explicitly states that founding members are "determined to reduce their dependence on imported oil" (IEA 1974). Yet, as we show below, policies varied widely despite common goals.

The oil shocks offer an ideal setting to test our arguments. Government efforts to pursue economic transformations can go hand-in-hand with institutional reforms, confounding the effect of institutions. An obvious example of this is post-communist transitions, but efforts to create independent central banks or regulatory agencies as part of broader economic reforms pose similar challenges. In all of the countries we examine, institutions are clearly exogenous: the institutional variables we hypothesize long predate the 1973 oil shock. Furthermore, based on the data we describe below, none of the countries saw a meaningful shift in the variables we use to measure institutions in the immediate period surrounding 1973.

Another advantage of the oil shocks is timing. Government efforts to pursue economic transitions are often idiosyncratic and occur gradually or at different points in time: this was the case with the shift to export-oriented development among East Asian countries and cross-national responses to climate change. Even the COVID-19 pandemic has affected different countries at different moments in time and with varying severity. The oil price shock was exogenous, simultaneous, and imposed essentially the same change in oil prices across OECD countries. The shocks also elicited simultaneous, public commitments by all OECD governments to pursue transitions away from oil. The shock thus allows us to account for potential confounders such as technological change, learning from prior transitions in other states, and idiosyncratic changes in government preferences for reform.

We utilize a mixed methods research design. First, we use panel data to examine the association between institutions and energy policy outcomes quantitatively. Second, we show in detail how institutions shaped policy responses in three countries (France, Germany, and the UK) using case studies and discourse network analysis. To operationalize supply-side and demand-side measures, we focus on policies in two sectors that were particularly large consumers of oil: electricity generation and transportation.

In the case of electricity, governments sought to encourage fuel switching away from oil and toward coal, nuclear, or renewable energies. Reforming the electricity supply system entailed transition costs for oil producers, coal producers, and electric utilities. Expanding coal to substitute for oil was relatively low cost, since oil-fired plants could be converted to coal and continue operation. However, expanding into relatively new technologies, such as nuclear and renewables, represented a more significant transition and meant writing off assets early and incurring major capital investment costs. Lastly, reduced dependence on oil would decrease demand for sector- 
specific skills and jobs. We measure each country's supply-side policy response using data from the IEA on the percentage of electricity generated from oil for 18 OECD countries.

On the demand side, transportation fuels were the primary way that the average household directly consumed oil. Moreover, these fuels comprised a substantial portion of overall oil consumption in most industrialized countries. Politicians sought to encourage conservation through taxes and fees, fuel-efficiency standards, and speed limits, among other policies. Costs were imposed costs on households either directly, as they paid more for gasoline or vehicle registration, or indirectly, as they invested in more fuel-efficient automobiles. To measure each country's demand-side policy response, we compiled an original dataset of gasoline tax rates across the 18 OECD countries from national and international sources (see supporting information). Gasoline taxes are especially useful to test our arguments because they impose direct and highly visible costs on voters. For both the supply- and demand-side analysis, we examine the period from 1965 to 1985, a roughly symmetrical period around the 1973 oil shock.

\section{Quantitative Analysis}

We expect two types of institutions to facilitate transformational policies on the demandside: PR electoral rules that can insulate politicians from voter backlash or robust welfare states that can compensate voters for higher energy costs (H1 and H3). To measure electoral rules, we code each country dichotomously based on whether they used majoritarian rules for lower-house elections (Armingeon et al. 2016). Measuring welfare states is notoriously difficult (Clasen and Siegel 2007). In the interest of parsimony, we rely on Esping-Andersen's_ (1990) typology, distinguishing between countries with conservative or social democratic welfare states on the one hand from those with liberal regimes. Based on our theoretical expectations, we code countries with either PR electoral rules or social welfare states as 1 for demand-side institutions. Countries with majoritarian electoral rules or liberal regimes are coded as 0 .

In the case of supply-side policies, we expect two institutions to be associated with transformative change: bureaucratic autonomy and corporatism ( $\mathrm{H} 2$ and $\mathrm{H} 4)$. There are no existing quantitative measures of bureaucratic autonomy that extend back to the 1970s. Measuring bureaucratic autonomy is challenging (Fukuyama 2013), particularly for historical periods in which survey-based measurement is impractical. To do so, we rely on qualitative scholarly work on states and bureaucracies (Johnson 1982; Lucas 1985). France, Japan, and Belgium are routinely singled out as having had strong, autonomous bureaucracies during this period. More recent survey-based measures also rank these three countries as having the most "closed" public administrative systems, consistent with prior qualitative work (Dahlström Lapuente, and Teorell 2010). To measure corporatism, we use Lehmbruch $\underline{\text { L }} \underline{\text { s }}$ _(1984) ordinal classification from the time period, coding countries as corporatist if they were characterized by either strong or medium corporatism. We code countries with autonomous bureaucracy or corporatist institutions as 1 for our measure of supply-side institutions. All other countries are coded 0. 
To formally test our hypotheses, we estimate the following equation:

$$
Y_{i t}=\beta_{1} D_{i t}+\beta_{2} I_{i t}+\beta_{3} D_{i t} * I_{i t}+\beta^{\prime} X_{i t}+\alpha_{i}+\gamma_{t}+e_{i t}
$$

where $Y_{i t}$ is the outcome of interest in country $i$ in year $t ; D_{i t}$ is a dummy variable for the 1973 oil price shock, which equals 1 from 1973 onwards and 0 before; $I_{i t}$ is the institutional grouping of interest; $X_{i t}$ is a vector of control variables; $a_{i}$ are country fixed effects; $\gamma_{t}$ are year fixed effects; and $e_{i t}$ is the error term. The two-way fixed effects model is akin to a difference-in-differences (DiD) approach, where the "treatment" is measured by $D_{i t} * I_{i t}$. It represents exposure to the 1973 oil price shock and having a particular set of institutions.

We include several control variables in the models. Governments with large oil reserves may have faced less pressure to move to different energy sources after the shock. To control for this possibility, we include domestic oil production (kilotonnes per capita). We also include real GDP growth, real GDP per capita, inflation, and unemployment to control for changes in countryspecific macroeconomic conditions, which may affect the ability of governments to impose costs or negotiate compensation.

In demand-side models that analyze gasoline taxes, we include two additional controls. First is urbanization, measured as the number of people living in urban areas as a percentage of the total population. It may be less politically risky increase fuel taxes when urbanization is high, since voters drive shorter distances and can more readily switch to public transportation. Second, we control for the number of vehicles per person. High levels of vehicle ownership indicate high reliance on fuel, which may generate greater resistance to high gasoline tax rates.

We also control for several political variables that could account for how quickly governments responded to the energy shock. We control for partisanship using the percentage of cabinet seats held by left parties, as progressive parties may have been more open to altering the status quo compared to conservative parties. We include a measure for political constraints (Henisz 2002) to account for the ability of veto players to stymie energy transitions for reasons unrelated to our institutional variables. We also include a dichotomous measure of single-party control of government, as the need for compromise under coalition government may have slowed transitions (Knotz and Lindvall 2015). These variables are potential alternative mechanisms through which political systems in different countries might have produced distinct patterns of response. However, controlling for these variables could be problematic, as they are also plausibly consequences of our institutional variables of interest. We thus include them in our models separately from the economic control variables.

Table 1 presents the results of this analysis. We turn first to the supply-side transition away from oil in electricity generation (Models 1-3). Our main variable of interest is the interaction between the price shock and the supply-side institutional dummy variable. The first model excludes the economic and political control variables. We see that following the 1973 price shock, countries with autonomous bureaucracies and corporatist institutions reduced electricity generation from oil by around 8 percentage points more than pluralist countries with weak 
bureaucracies, relative to a sample mean of 19 percent. This is a substantively large difference. As Model 2 and 3 show, the inclusion of economic and political control variables makes very little difference in the results.

The demand-side model for gasoline taxation is presented in Model 4-6. The interaction term is positive and statistically significant, indicating that countries with PR or welfare state institutions increased tax rates by around 8 cents per liter more than majoritarian countries with liberal regimes after the price shock, relative to a sample mean of 17 cents. Again, this is a substantively large difference for a key policy lever. As with the supply-side models, the inclusion of control variables in Models 5-6 produce very similar results.

To evaluate the robustness of the results, we carried out several checks (see supporting information). First, we reran the models with country-clustered standard errors. Second, we reran the models including a lagged dependent variable. Lastly, we replaced the 1973 price shock dummy variable with each country's dependence on imported oil in 1972 to test for heterogeneous treatment effects. In all cases, the substantive findings remained unchanged. 
Table 1. OLS Regressions with Two-Way Fixed Effects

\begin{tabular}{|c|c|c|c|c|c|c|}
\hline & $\begin{array}{c}(1) \\
\text { Electricity } \\
\text { generation } \\
\text { from oil } \\
(\% \text { of total })\end{array}$ & $\begin{array}{c}(2) \\
\text { Electricity } \\
\text { generation } \\
\text { from oil } \\
(\% \text { of total })\end{array}$ & $\begin{array}{c}\text { (3) } \\
\text { Electricity } \\
\text { generation } \\
\text { from oil } \\
\text { (\% of total) }\end{array}$ & $\begin{array}{c}(4) \\
\text { Gasoline } \\
\text { tax rate } \\
\text { (USD/liter) }\end{array}$ & $\begin{array}{c}(5) \\
\text { Gasoline } \\
\text { tax rate } \\
\text { (USD/liter) }\end{array}$ & $\begin{array}{c}(6) \\
\text { Gasoline } \\
\text { tax rate } \\
\text { (USD/liter) }\end{array}$ \\
\hline Oil price shock (1973) & $\begin{array}{l}-2.71 \\
(3.12)\end{array}$ & $\begin{array}{c}1.67 \\
(6.35)\end{array}$ & $\begin{array}{c}1.71 \\
(6.31)\end{array}$ & $\begin{array}{c}0.05^{*} \\
(0.01)\end{array}$ & $\begin{array}{l}0.15^{*} \\
(0.02)\end{array}$ & $\begin{array}{c}0.15^{*} \\
(0.02)\end{array}$ \\
\hline $\begin{array}{l}\text { Oil price shock (1973)* } \\
\text { Supply-side institutions }\end{array}$ & $\begin{array}{l}-8.37^{*} \\
(1.92)\end{array}$ & $\begin{array}{l}-9.62^{*} \\
(2.11)\end{array}$ & $\begin{array}{l}-9.09^{*} \\
(2.10)\end{array}$ & & & \\
\hline $\begin{array}{l}\text { Oil price shock }(1973)^{*} \\
\text { Demand-side institutions }\end{array}$ & & & & $\begin{array}{l}0.08^{*} \\
(0.01)\end{array}$ & $\begin{array}{c}0.09^{*} \\
(0.01)\end{array}$ & $\begin{array}{l}0.09^{*} \\
(0.01)\end{array}$ \\
\hline Economic Control Variables & No & Yes & Yes & No & Yes & Yes \\
\hline Political Control Variables & No & No & Yes & No & No & Yes \\
\hline Country FE & Yes & Yes & Yes & Yes & Yes & Yes \\
\hline Year FE & Yes & Yes & Yes & Yes & Yes & Yes \\
\hline Countries & 18 & 18 & 18 & 18 & 18 & 18 \\
\hline$N$ & 378 & 378 & 378 & 376 & 376 & 376 \\
\hline
\end{tabular}

Note: Standard errors in parentheses. ${ }^{*} p<0.05$ 


\section{Generalized Synthetic Control}

Although the two-way fixed effects model has been a ubiquitous approach for estimating causal effects in a panel setting, recent work has called into question the common assumption that the model can simultaneously adjust for both unit-specific and time-specific unobserved confounders (Imai and Kim 2020). We thus consider an alternative design-based approach for causal inference, the generalized synthetic control method (Xu 2017).

The synthetic control method uses key predictors to construct a control case that closely resembles a treated country of interest (Abadie, Diamond, and Hainmueller 2010). It is then possible to examine the divergence of the dependent variable of interest between the treated country and synthetic control. The method was originally applied to examine the impact of terrorism on economic variables in the Basque country, and it has been subsequently applied to examine the impact of a wide range of political phenomena (Abadie, Diamond, and Hainmueller 2015; Abadie and Gardeazabal 2003; Beckley, Horiuchi, and Miller 2018; Billmeier and Nannicini 2012; Lipscy and Lee 2019). The generalized synthetic control method extends this to cases of multiple treated units and treatment periods ( $\mathrm{Xu}$ 2017).

For our analysis, we use the same data used earlier in Table 1. The dependent variables are the same: oil share of power generation for the supply side and gasoline taxes for the demand side. The independent variables are also the same: countries are dichotomously coded as treated after 1973 if they are associated with insulation or compensation institutions as described earlier. Treatment is thus defined as the joint presence of an impetus for government-led transformation generated by the oil shock - and institutions theoretically predicted to facilitate transformation.

As predictor variables, we use the economic control variables used in Model 2 and 5 in Table 1, which are not subject to endogeneity concerns. Standard errors are generated using the parametric bootstrap procedure, as we have fewer than 40 units in the treatment group (Xu 2017), and we use the expectation-maximization algorithm proposed by Gobillon and Magnac (2015 which takes advantage of treatment group information in the pre-treatment period.

The results for the supply side are presented in Figure 3. The figure depicts the trend in oil share of electricity production for countries with supply-side institutions in our sample (solid line), along with the estimated level of oil share in the counterfactual scenario that these countries were not characterized by supply-side institutions. As the figure shows, the evolution of oil share of electricity production for countries with supply-side institutions is well matched with the counterfactual until the 1973 oil shock, but a large divergence opens thereafter, with oil share in treated countries falling relatively rapidly. As we show in the supporting information, the difference between treated and counterfactual countries is statistically meaningful based on uncertainty estimates from the parametric bootstrap procedure.

The analogous results for the demand side are presented in Figure 4. As with the supplyside figure, the treated and counterfactual trends are well-matched until the 1973 oil shock. After 1973, a large divergence opens up with treated countries exhibiting a much sharper increase in 
gasoline tax rates compared to the counterfactual. These results are consistent with the findings from the two-way fixed effects model reported in Table 1.

Taken together, the results offer support for our theoretical arguments that institutions structured the ability of governments to reduce their countries' dependence on oil after the 1973 price shock, and in doing so, hastened or impeded energy transitions. On the supply side, countries with autonomous bureaucracies or high levels of corporatism shifted away from oil more rapidly in the electricity sector. On the demand side, countries with PR electoral rules or strong welfare state institutions adopted relatively higher gasoline tax rates. In the supporting information, we also show that countries with both demand- and supply-side institutions meaningfully reduced their total economywide oil consumption compared to the counterfactual characterized by neither set of institutions.

Figure 3: The Effect of Supply-Side Institutions on Oil Share of Electricity Production (Generalized Synthetic Control)

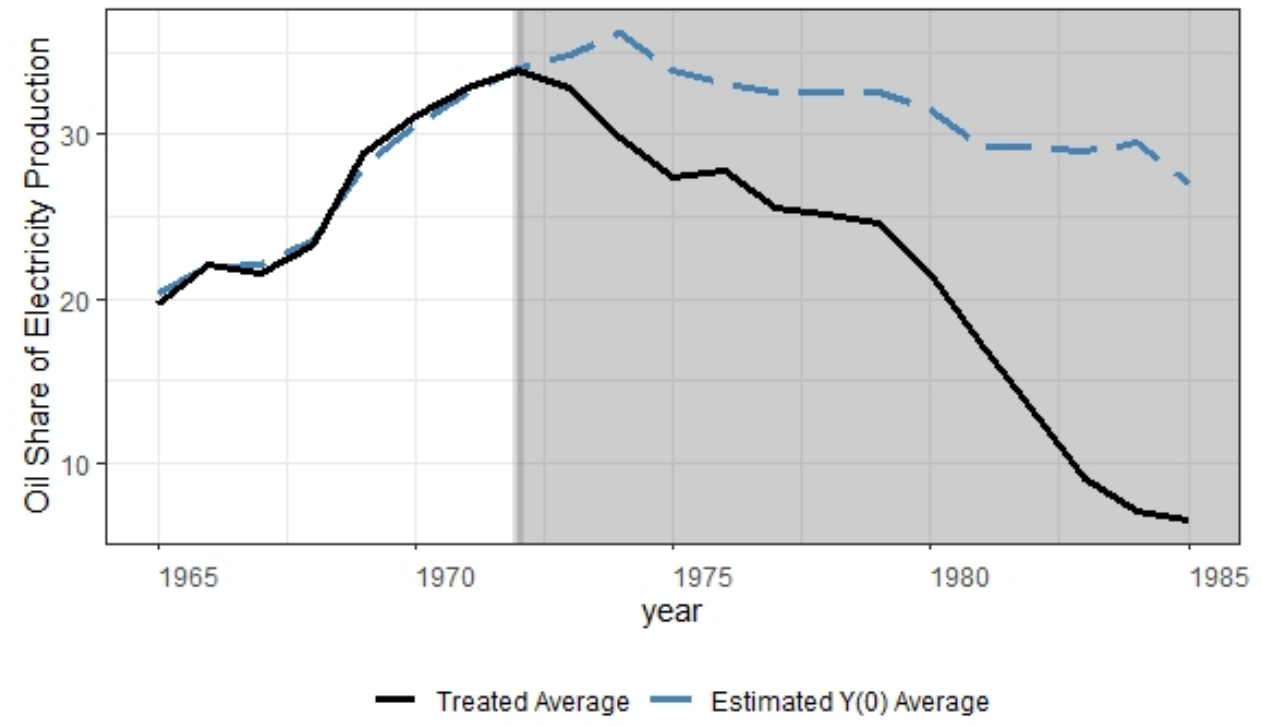

Note: The evolution of oil share of electricity production for countries with supply-side institutions (solid line) is well matched with the counterfactual (dotted line) until the 1973 oil shock, but a large divergence opens up thereafter, with oil share in treated countries falling relatively rapidly. 
Figure 4: The Effect of Demand-Side Institutions on Gasoline Taxes (Generalized Synthetic Control)

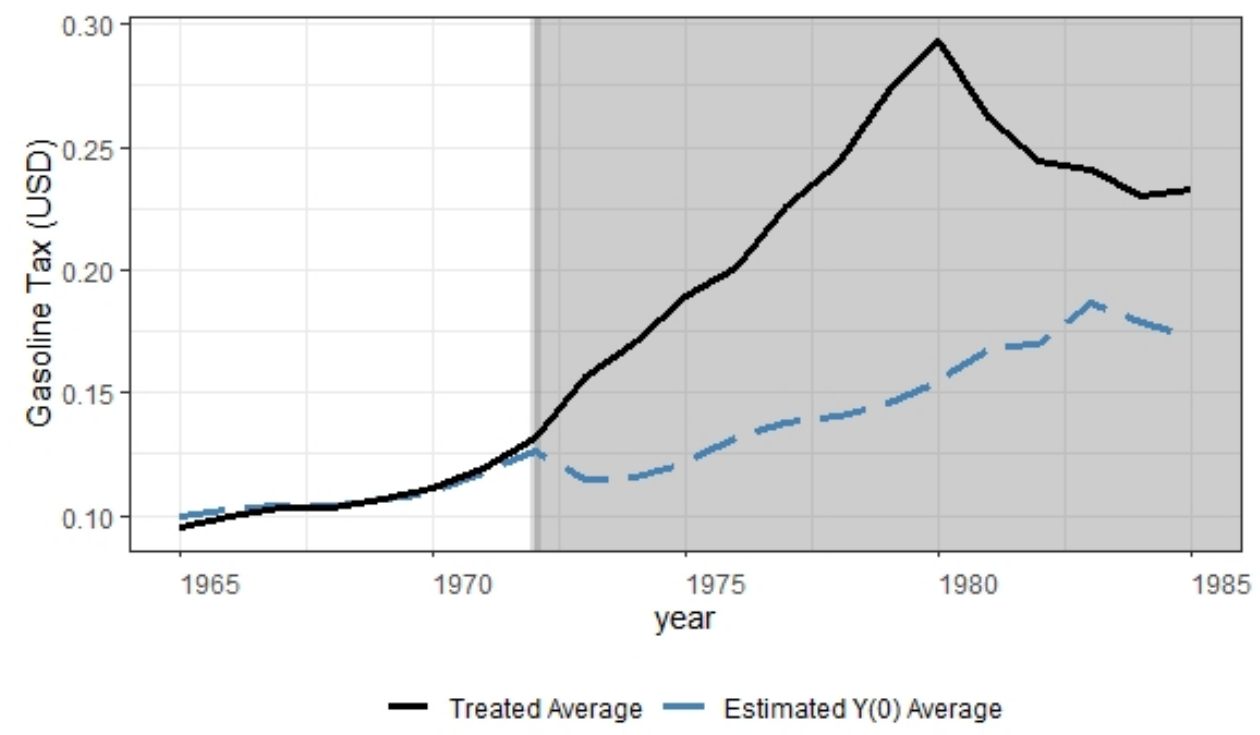

Note: The evolution of gasoline taxes for countries with demand-side institutions (solid line) is well matched with the counterfactual (dotted line) until the 1973 oil shock, but a large divergence opens up thereafter, with taxes in treated countries increasing relatively rapidly.

\section{Case Studies}

While the quantitative analysis provides evidence consistent with our proposed hypotheses, they do not allow us to observe the political processes and decision-making that produced divergent policy outcomes. In this section, we will examine three country case studies - the United Kingdom, Germany, and France - in order to investigate the causal mechanisms that enabled policymakers to shift their economies away from oil after 1973.

The countries were chosen based on several criteria. First, we made an effort to control for obvious confounders. We chose countries with large, sophisticated economies where energy supply problems could not be resolved through a simple policy choice, such as the construction of several nuclear power plants. We also avoided countries with significant domestic oil production during the price shocks-Australia, Canada, and the United States-which could partially substitute for the loss of foreign oil supplies (although we do not find evidence for this in the quantitative analysis). In the case of the UK, North Sea oil was discovered in the late 1960s, but production did not begin until 1975.

Second, we selected countries to capture the full range of institutional variation. During the oil shocks, the United Kingdom and France used majoritarian electoral rules with single member districts, while Germany utilized a mixed member proportional system. Germany and France had robust welfare state institutions, while the UK had a liberal regime. France was known for dirigisme, while bureaucratic autonomy was limited in the UK and Germany. In terms of interest 
group intermediation, Germany was characterized by corporatism, while France was a mixed case and the UK was the least corporatist.

The configuration of cases helps us to isolate the effect of each independent variable and related causal mechanism of interest. Based on variation in electoral systems, we expect more ambitious demand-side measures in Germany, as the government should be better insulated from electoral backlash compared to the UK. France is also majoritarian, but given its robust welfare state, we expect demand-side policies coupled with compensatory measures. Based on variation in bureaucratic insulation and interest group intermediation, we expect supply-side transitions to be more ambitious in France and Germany compared to the UK. In France, supply-side transitions should be state-led, technocratic, and able to manage resistance from entrenched producer interests and civil society. In Germany, we expect policy shifts not based on insulation but rather corporatist negotiations with producers and the provision of compensation. In the UK, where the government lacked both insulation and the capacity to compensate, we expect retreat.

The case studies draw on contemporaneous primary and secondary sources. Furthermore, we include findings from discourse network analysis of an original dataset of newspapers articles. The data quantifies political processes and discourse by coding newspaper articles in Germany and the UK. For Germany and the UK respectively, we coded 466 and 454 articles published between 1973 and 1985 about energy policy from the center-right daily newspapers, the Frankfurter Allgemeine Zeitung and The Times. We coded actors involved in energy policy, their policy goals and preferences, and their participation in government meetings as reported in the newspapers. Details about the data gathering and coding procedure are available in the supporting information.

\section{Institutional sources of demand-side policies}

Germany adopted a number of demand-side measures in both the electricity and transport sector. In electricity, measures focused on energy efficiency mandates, in particular the Energy Conservation Act of 1976 advanced energy efficiency regulation. One key demand-side measure in the transport sector was to increase gas taxes (Tait and Morgan 1980), which pushed up gasoline prices by 27 percent by 1980 (Table 2).

Table 2. Percentage change in real household energy prices between 1972 and 1980

\begin{tabular}{|l|r|r|r|r|r|}
\hline & Gasoline & $\begin{array}{r}\text { Heating } \\
\text { oils and } \\
\text { kerosene }\end{array}$ & $\begin{array}{r}\text { Natural } \\
\text { gas }\end{array}$ & Coal & \multicolumn{1}{c|}{$\begin{array}{c}\text { Total } \\
\text { energy }^{\mathrm{a}}\end{array}$} \\
\hline Germany & +27.00 & +211.50 & +7.00 & +38.50 & +50.83 \\
\hline France & +32.00 & $+172.00^{\mathrm{b}}$ & +14.88 & +61.65 & +38.50 \\
\hline UK & +20.00 & +81.40 & -40.50 & +1.05 & -6.00 \\
\hline
\end{tabular}

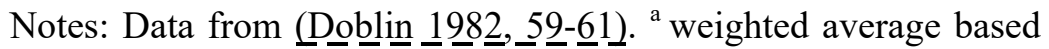
on consumption of each fuel. ${ }^{\mathrm{b}}$ price change between 1970 and 1980. 
The government also imposed visible costs on consumers to finance the compensation of producers. Two thirds of the subsidies to utilities for the expansion of coal-fired generation capacity — 9 billion DM between 1974 and 1977 alone - were funded through duties levied on consumer electricity bills (Schmitt 1982). The so-called "coal penny" was so visible to consumers that it had its own colloquial name. One third of the subsidies had to be paid by utilities, but those were passed on to consumers (Jacobsson and Lauber 2006). The German parliament discussed and approved the coal penny in the second half of 1974, with the Social Democrats and the Liberals holding a majority. Strong cross-party support emerged for the measure. Parliament even mandated that utilities break out the coal penny share on customers' bills for reasons of consumer protection, revealing the lack of concern among members of parliament about potential electoral backlash. The parliament specifically rejected funding subsidies through the general budget, which the Federal Council preferred (Bundestag 1974). By 1980, German real household energy prices had risen by over $50 \%$ (Table 2). In addition to electoral insulation, the German government took advantage of established welfare state institutions to compensate consumers for energy price increases. In December 1973, the parliament debated and agreed on financial support for lowincome households to pay higher heating fuel costs (Bundestag 1973).

In the UK, the government's demand-side response aimed to increase energy conservation, while also keeping energy prices low. Energy efficiency plans included standards for buildings, indoor temperature limits, and reduced speed limits (Mallaburn and Eyre 2014). Yet a parliamentary committee found that there was a "general lack of urgency" for implementing them (Mallaburn an_ and Eyre_2014 225). Households were shielded from steep energy price increases through price controls and subsidies ( until 1976, which, given high levels of inflation, led to a steep decline in real rates. A value-added tax (VAT) was applied to road fuels beginning in 1974. However, because the government set maximum retail prices for gasoline, consumers initially saw only a $20 \%$ rise in the cost of fuel (Dargay 1990,29). Once controls were lifted in 1975, prices shot up by $70 \%$ for gasoline and $40 \%$ for diesel (Dargay 1990, 29). In response, the VAT on fuel was cut in half in 1976. While excise rates began to increase again after the 1979 price shock, the real price of fuel had risen by only 20\% between 1972 and 1980; compared with 32\% in France and 27\% in Germany (Table 2). The UK government used the general budget to subsidize electricity and gas for households (Helm2004__C 2; Parliament_1974). Moreover, neither the VAT nor any other taxes were applied to these energy sources. All told, government policy helped to reduce real household energy prices by $6 \%$ between 1972 and 1980 (Table 2).

Our discourse network analysis of newspaper articles confirms the high political salience of energy costs in the UK compared to Germany, consistent with our expectations based on variation in demand-side institutions. In Germany, only about $10 \%$ of the discourse among government and private actors raised energy costs as a concern, while about $48 \%$ raised energy security and $42 \%$ environmental concerns (Figure 5). On the other hand, in the UK, $47 \%$ of statements relate to energy costs, a share exceeding energy security or environmental concerns 
(Figure 5). Concerns about energy costs loomed large in the UK policy response to the oil shock, while the German government had a freer hand to focus on transformative policy priorities.

Figure 5: Relative importance of energy policy goals in German and British media discourses (1973-1985)

\section{Energy Costs}

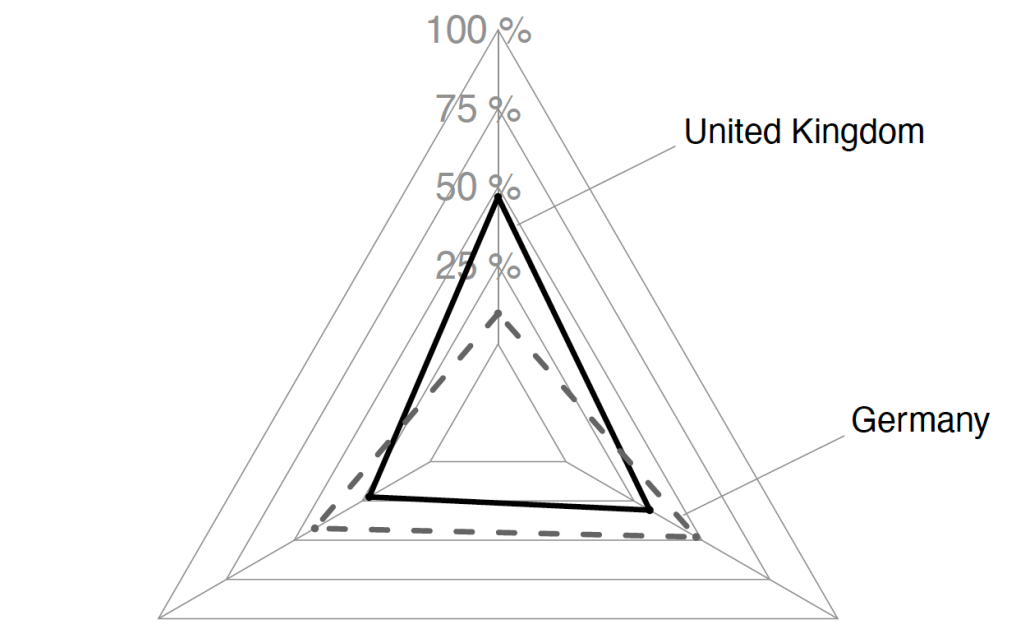

Environment

Energy Security

Note: The radar chart depicts the relative importance of energy policy goals (in percentages) based on systematically coded newspaper reports about actors' goals. In the German discourse, energy security is a major concern for actors $(47.9 \%, \mathrm{~N}=69)$, followed by the environment $(42.4 \%, \mathrm{~N}=61)$ and energy costs $(9.7 \%, \mathrm{~N}=14)$. In the $\mathrm{UK}$, actors emphasize costs $(46.8 \%, \mathrm{~N}=73)$ over energy security $(30.8 \%, \mathrm{~N}=48)$ and the environment $(22.4 \%, \mathrm{~N}=35)$.

France responded to the oil shocks with more ambitious measures than other majoritarian countries, including the UK. This is consistent with our expectations based the institutional mix of majoritarian electoral rules and strong welfare state institutions, which leaves open the compensatory route for demand-side transformation. Energy consumption was subject to both rationing and incremental price increases starting in 1974. Tax levies on fuel consumption generally remained in place even after oil prices declined in the 1980s. Government policy worked to increase the price of all household energy carriers (Table 2). By 1980, consumers were paying around 38\% more for energy compared to 1972.

Importantly, French social welfare spending expanded dramatically in the period after the oil shocks, cushioning the blow of new energy levies. Spending on social benefits consistently increased by double digits annually after the oil shocks, and much of this was financed by shifting the government budget into deficit (OECD 1979, 43-44). Social transfers rose from 19.4 percent of GDP to 25.3 percent between 1974 and 1981 (Palier 1999, 255). Increases in social expenditures in France were the highest among industrialized countries in the 1970s (Alber 1988). The oil shock 
of 1973 brought new social strife as poverty became a wide-spread concern. In the 1970s, the French government expanded several social welfare programs, including early retirement, unemployment programs, income support/minimum wage programs, and income for disabled workers (Vail 2010). The early-retirement schemes were designed specifically to "compensate for ... pre-mature poverty due to work situation or difficult economic circumstances," as a government document put it (in: Vail 2010, 60). French demand-side measures during the oil shocks thus reflected a mix of price incentives to promote energy conservation and economic compensation through broader social spending measures.

\section{Institutional sources of supply-side policies}

Germany's supply-side response focused on increasing nuclear power production and domestic coal use in electricity generation through significant subsidies (Jacobsson and Lauber 2006, Storchmann 2005). The expansion of nuclear capacity reached its peak in the 1970s, when 15 reactors were built (Hake et al. 2015). The Federal Energy Program of 1981 commissioned almost a dozen additional nuclear power plants and seven new coal plants (Renn and Marshall 2016). Cross-party support backed the nuclear consensus until the late 1980s (Hake et al. 2015). As a result, we observe an increase in the share of nuclear electricity production in the following years; it peaked in 1997 and declined afterwards. The use of oil in electricity production declined steadily. Supply-side policies for renewables initially entailed investments in research and development, beginning in 1974. Deployment incentives for solar followed in 1977, albeit at a small scale. Until the mid-1990s, renewables grew modestly, while their total share in electricity production remained relatively stable.

Germany's supply-side response exhibits the signs of broad government-industry-labor coordination on the electricity mix, with a focus on nuclear and coal (Matthews 2001). The government supported both domestic coal and nuclear with significant subsidies, thus compensating producers in the supply-side transition. It was an integrative strategy that saw a role for both coal and nuclear in the future electricity mix. This was important to mitigate opposition from coal miners to an energy diversification strategy focused solely on nuclear. For example, the CEO of Ruhrkohle, a major coal producer, argued that coal could not just serve as the fuel of last resort when supply was short, but needed to be integrated into a long-term energy policy. Otherwise, production capacity would need to be reduced (FAZ 1975). Renewable energy policies were largely a form of accommodation of demands of the environmental movement (Hake et al. 2015), rather than part of the core govt-industry-labor coordination. At the time, the environmental movement focused on pro-renewables and anti-nuclear mobilization but did not yet target coal.

The discourse network analysis confirms the distinct pattern of corporatist state-business relations in the German energy sector. Based on the highly organized, corporatist policymaking environment in Germany, we expect government negotiations with economic losers to involve fewer actors and require fewer meetings as compensatory arrangements alleviate concerns over transformative policy change. Focusing only on the meetings between government and policy 
losers (i.e., utilities and oil industry), we indeed find that meetings were smaller in Germany (on average, they involved 1 vs. 1.3 distinct policy loser organizations for Germany and UK respectively) and fewer total losers participated in meetings with the government (7 vs. 14). Furthermore, fewer meetings were held with losers (11 vs. 28) in Germany compared to the UK. In Germany, negotiations took place between the government and relatively few organized losers, reducing the transaction costs of compensatory bargaining and facilitating a supply-side energy transformation.

The UK made serious efforts to transform its state-owned electricity system by securing oil supplies and expanding coal, nuclear, and renewables. However, policy ultimately failed to generate transformative change. Lacking bureaucratic autonomy, policymaking was highly politicized, especially in the case of nuclear. At the same time, without strong corporatist institutions, governments struggled to negotiate compensatory arrangements with economic losers, generating distributional struggles over fuel choice and stalling reforms.

UK government actors, especially the civil service, viewed nuclear as the most costeffective way to meet the country's long-term energy needs and sought to expand it throughout the 1970s ( the government could not overrule or reach compensatory bargains with opponents. Interest groups associated with the fossil fuel sector viewed nuclear as a threat and lobbied against it (Williams 1980 _ Ch_ 7). Unable to reconcile this distributional struggle through insulation or compensation, the government ultimately reversed course and cancelled its nuclear programs (Pearson 2012 20 5). Of the planned 19GW of capacity to be installed by 1991, less than 3GW was added by 1985 .

The UK's response can be broadly characterized as less focused on transforming the energy sector and more on securing oil supplies through bilateral agreements with Middle Eastern exporters and diversifying oil imports away from OPEC sources (Helm 2004,36 ). The government also moved to develop recently discovered North Sea oil fields. With transformative change stymied, the UK ultimately continued to rely on oil while seeking to achieve energy security by shifting in favor of 'friendly' OPEC, non-OPEC, and domestic oil.

French policymaking under the Fifth Republic has been characterized by dirigisme, strong executive authority and policymaking under the leadership of an autonomous bureaucracy (Suleiman 1974; Wilson 1988). The autonomy of French government policymaking was particularly pronounced during the 1970s oil shocks, as both the French utilities and oil sectors were state-owned and hence subject to direct government control. Among large OECD countries, France was unique in implementing a large, rapid supply-side transition away from oil in favor of nuclear power. The French nuclear program preceded the oil shocks. The 1973 crisis, however, led the country to dramatically accelerate and expand nuclear power development (Wade 1980, Ikenberry 1986). In 1974, Prime Minister Pierre Messmer announced what was to become an eponymous plan to dramatically transition France toward nuclear power. The declared goal was that by 1985 , more than 60 percent of France's electricity needs were to be met by nuclear energy.

The expansion of nuclear power through Electricité de France (EdF), the state-owned utility, was a distinctly technocratic process, insulated from the opposition of policy losers. The 
French parliament neither debated the expansion of nuclear power nor voted on it. EdF rapidly built out new nuclear plants while ignoring or suppressing large-scale, sometimes violent protests (Wade 1980). The nuclear share of French electricity production rapidly expanded from $8 \%$ in 1973 to the $70 \%$ range by the mid-1980s, eliminating the need for oil in electricity production. As predicted, the supply-side transformation in France took advantage of institutional insulation and proceeded without meaningful compensation of opposing voices.

\section{Implications for Climate Policy}

Our theory of the institutional sources of economic transformation and evidence from the oil crisis offers important lessons for the emerging low-carbon transition in response to climate change. The goal for the ongoing transition is to reduce greenhouse gas emissions. Today's transition is not driven by a sudden global price shock. Instead, domestic and international political mobilization plays a central role, while the steep declines in the price of renewable energy technologies, such as wind and solar photovoltaics, also increasingly matter. Countries again vary significantly in their policy choices and the pace of the low-carbon transition. Initial evidence suggests, however, that the mechanisms of insulation and compensation are also central to policymakers' ability to overcome opposition from fossil-fuel incumbents to drive a clean energy transition.

Recent work has shown the role of electoral institutions in enabling governments to adopt demand-side climate policies that impose costs on consumers. High levels of electoral competition decrease fossil fuel tax rates (Finnegan 2018). Moreover, high-income democracies with PR electoral systems have adopted more stringent climate policies, measured as how government policy increase the cost of carbon-based energy prices (Finnegan 2019). Similarly, countries with proportional electoral rules were shown to adopt more stringent energy efficiency policies. For example, Japan adopted ambitious energy efficiency and renewable energy after the oil crises, when it had proportional electoral rules. After electoral reform toward a majoritarian system in 1994, Japan's entered a period of policy retrenchment (Lipscy 2018).

Research has also demonstrated how insulation through the delegation of policy-making to autonomous agencies has played an important role in California's climate policy and energy transition (Meckling and Nahm 2018b). California has majoritarian voting rules and pluralist interest intermediation. It is thus badly equipped to drive major structural change in the energy sector. The state possesses, however, the California Air Resources Board (CARB), a highly skilled and autonomous environmental agency. The agency built its autonomy and expertise over decades, initially focusing on air pollution. In climate and clean energy policy, the California legislature intentionally delegated key policy decisions against the opposition of industry groups to CARB. The landmark California Global Warming Solutions Act of 2006 and subsequent climate framework legislation was very brief, broadly delegating policy design and implementation to the agency.

Next to insulation, compensation has also been critical to recent climate policy advances. To achieve its 2030 emission reduction target, Germany needs to phase out the use of lignite coal 
in power generation. The government set up the "Commission for Growth, Structural Transformation, and Employment." It appointed 31 representatives of industry, German states, labor unions, environmental groups and science to the commission in June 2018. The composition of the commission reflects an expanded form of corporatism or coordinated policymaking. The commission's mandate was to develop a proposal for phasing out coal, achieve the 2030 emission reduction targets for the power sector, and create employment in regions impacted most by the coal phase-out. The mandate explicitly included public investments in economic transition (Bundesregierung 2018). The commission recommended a coal phase-out by 2038 , tied to a $40-$ billion-euro public investment package for the compensation of those bearing the costs of the transition. This includes coal-mining regions, energy-intensive industry, electric utilities operating coal-fired generation plants, and coal workers. The federal government was not bound by the commission's proposal, but it largely adopted the "coal consensus" and submitted a bill to German parliament in summer 2019 to turn the recommendations into legislation. The corporatist bargain stuck.

The role of the welfare state in compensating consumers in low-carbon transitions is less clear and a worthy topic for future research. A growing body of survey work examines the salience of compensation schemes among the general public to advance climate policy, in particular in the US context (Gaikwad, Genovese, and Tingley 2020). It may be that consumer compensation is less feasible in jurisdictions with less robust welfare state institutions. However, we should also be mindful of secular shifts, such as population aging and large public debt burdens, which may constrain the role of demand-side compensatory measures in the low carbon transition relative to the 1970s.

\section{Conclusion}

In this article, we set out to explain why some advanced economies are more effective in promoting transformative economic change than others. Building on a rich tradition in comparative and international political economy, we developed an institutional theory of economic transformation and tested it in the context of energy policy. We argue that institutions can enable governments to impose costs on producers and consumers through two central mechanisms: insulation and compensation. The institutional sources of insulation and compensation vary across policies that primarily impose costs on consumers and policies that target producers.

We operationalized our theory by examining four types of institutions that affect insulation and compensation in advanced industrialized countries. Proportional electoral rules tend to provide higher levels of insulation than majoritarian rules. Thus, jurisdictions with proportional electoral systems are more likely to adopt transformative demand-side measures that rely on manipulation of prices. Our quantitative analysis and the case studies support this. After the 1973 price shock, countries with PR increased gasoline taxes significantly more than countries with majoritarian rules. Similarly, bureaucratic autonomy can insulate the policymaking process to some degree from organized producer interests. Our quantitative analysis and case studies suggest autonomous 
bureaucracies played an important role energy transformations, such as the French expansion of nuclear power in the 1970s.

We also highlight the role of compensatory mechanisms in economic transformations. In settings where relations between the government and organized interests are highly coordinated over time, integrative distributive bargains are more easily struck. Such bargains are likely to include compensation for producers, as structural economic change creates economic losers. Our case study of Germany illustrates significant government-producer coordination and producer compensation in striking bargains on supply-side policies. In the case of France, we observed the implementation of demand-side policies in tandem with a large expansion in social welfare spending, which effectively compensated diffuse consumers who faced adjustment burdens stemming from higher energy costs.

Our theory and findings raise important questions for research on the politics of economic transformation. First, we operationalized our theory of insulation and compensation in the context of advanced democracies. Yet, these mechanisms are likely to play a role in enabling policymakers to adopt costly policies across a wider range of political systems. With the rise of China and other developing countries, the sources and mechanisms of economic transformation in developing countries and authoritarian countries have taken on greater substantive importance. Authoritarian systems vary significantly in their capability for economic transformation, for example, through the nationalization of resource extraction sectors (Mahdavi 2020). Domestic institutions likely condition the ability to adopt transformative policies, though these institutional sources at least partly vary from those in democratic contexts. Thus, a natural extension of our work is applying our theory of insulation and compensation to a wider set of political contexts.

Second, we demonstrate the institutional sources of initial policy choices in response to a price shock. Yet economic transformations, and infrastructure-heavy energy transitions in particular, are multi-decade processes that require policies to be durable and to evolve in view of long-term policy goals. This brings in questions of temporal dynamics that are gaining traction in the study of energy transitions (Rosenbloom, Meadowcroft, and Cashore 2019, Pierson 2004). Our data is suggestive, though not conclusive, that the same institutions and mechanisms that enable initial policy adoption play an important role in policy durability, through their effect on veto points, for example (Birchfield and Crepaz 1998). Future research needs to grapple with the institutional sources and mechanisms of long-term policy durability. For instance, a research design that examined country responses to the reverse oil shock of 1986, when the oil price dropped, could begin addressing the question of policy stability.

Our theory and findings have important implications for contemporary economic transformations, including the clean energy transition, the broader renaissance of industrial policy in Western economies, and policy responses to the COVID-19 pandemic. We expect the magnitude and pace of structural economic change to vary considerably across institutional settings. Liberal economies such as the United States largely lack the institutional sources for a policy-driven transition. For example, the United States has shied away from adopting costly climate policies, relying mostly on investing in low-carbon research and development, also central to President 
Biden's climate agenda. In the absence of electoral reform, we envision two pathways to economic change in jurisdictions without institutional sources of insulation and compensation. First, these countries may take advantage of spillover effects from jurisdictions with supportive institutions, which can reduce the cost of technologies that then allow for more market-driven transitions. The decline in the cost of solar photovoltaics and wind technologies and the subsequent global diffusion of these technologies reflect such a pattern. Even where policy-driven transformation is blocked, international cooperation to accelerate market-driven transformations may still be viable. Second, even in countries with low bureaucratic autonomy at the national level, it may be possible to create or exploit pockets of greater autonomy. This might mean agencies in sub-national jurisdictions or bureaucracies that have been operated with a degree of autonomy for other reasons, such as central banks or defense agencies. These may offer opportunities for policymaker insulation from producer backlash and thus for the adoption of supply-side policies. 


\section{References}

Abadie, Alberto, Alexis Diamond, and Jens Hainmueller. 2010. "Synthetic Control Methods for Comparative Case Studies: Estimating the Effect of California's Tobacco Control Program." Journal of the American Statistical Association 105(490): 493-505.

Abadie, Alberto, and Javier Gardeazabal. 2003. "The Economic Costs of Conflict: A Case Study of the Basque Country." American Economic Review 93(1): 113-32.

—. 2015. "Comparative Politics and the Synthetic Control Method." American Journal of Political Science 59(2): 495-510.

Aklin, Michael, and J. Urpelainen. 2018. Renewables: The Politics of a Global Energy Transition. Cambridge, MA: MIT Press.

Aklin, Michael, and Johannes Urpelainen. 2013. "Political competition, path dependence, and the strategy of sustainable energy transitions." American Journal of Political Science 57 (3):643-658.

Alber, Jens. 1988. "Is there a crisis of the welfare state? Crossnational evidence from Europe, North America, and Japan." European Sociological Review 4 (3):181-205.

Amsden, Alice H. 1989. Asia's Next Giant: South Korea and Late Industrialization. New York: Oxford University Press.

Armingeon, Klaus et al. 2016. "Comparative Political Data Set 1960-2014.” https://www.cpdsdata.org/.

Beckley, Michael, Yusaku Horiuchi, and Jennifer M. Miller. 2018. "America's Role in the Making of Japan's Economic Miracle.” Journal of East Asian Studies 18(1): 1-21.

Billmeier, Andreas, and Tommaso Nannicini. 2012. "Assessing Economic Liberalization Episodes: A Synthetic Control Approach." The Review of Economics and Statistics 95(3): 983-1001.

Birchfield, Vicki, and Markus ML Crepaz. 1998. "The impact of constitutional structures and collective and competitive veto points on income inequality in industrialized democracies." European Journal of Political Research 34 (2):175-200.

Bundesregierung. 2018. "Einsetzung der Kommission Wachstum, Strukturwandel und Beschäftigung." accessed July 18. https://www.bmwi.de/Redaktion/DE/Downloads/E/einsetzung-der-kommissionwachstum-strukturwandel-beschaeftigung.pdf? blob=publicationFile $\& v=4$.

Bundestag. 1973. 70. Sitzung. edited by Deutscher Bundestag. Bonn.

Bundestag. 1974. Bericht und Antrag des Ausschusses für Wirtschaft. Deutscher Bundestag.

Campbell, Andrea Louise. 2012. "Policy Makes Mass Politics." Annual Review of Political Science 15(1): 333-51.

Carpenter, Daniel. 2001. The Forging of Bureaucratic Autonomy: Reputations, Networks, and Policy Innovation in Executive Agencies, 1862-1928. Princeton University Press.

Clasen, Jochen, and Nico A. Siegel. 2007. Investigating Welfare State Change: The "dependent Variable Problem" in Comparative Analysis. Edward Elgar Publishing.

Colgan, Jeff D., Jessica F. Green, and Thomas N. Hale. 2020. "Asset Revaluation and the Existential Politics of Climate Change." International Organization:1-25. doi: $10.1017 / \mathrm{s} 0020818320000296$. 
Dargay, Joyce. 1990. Have Low Oil Prices Reversed the Decline in Energy Demand?: A Case Study for the UK. Oxford, UK: Oxford Institute for Energy Studies.

Esping-Andersen, Gosta. 1990. The Three Worlds of Welfare Capitalism. Cambridge: Polity.

Evans, Peter. 1995. Embedded Autonomy. States and Industrial Transformation. Princeton: Princeton University Press.

FAZ. 1975. "Kritik an der Europäischen Energiepolitik." Frankfurter Allgemeine Zeitung.

Finnegan, Jared J. 2018. "Changing Prices in a Changing Climate: Electoral Competitiveness and Fossil Fuel Taxation." Centre for Climate Change Economics and Policy Working Paper 341/Grantham Research Institute on Climate Change and the Environment Working Paper 307: 54.

—. 2019. "Institutions, Climate Change, and the Foundations of Long-Term Policymaking." Grantham Research Institute on Climate Change and the Environment Working Paper No. 321: 55.

Frye, Timothy. 2002. "The perils of polarization: Economic performance in the postcommunist world." World politics 54 (3):308-337.

Fukuyama, Francis. 2013. "What Is Governance?” Governance 26(3): 347-68.

Gaikwad, Nikhar, Federica Genovese, and Dustin Tingley. 2020. "Creating Climate Coalitions: Mass Preferences for Compensating Vulnerability in the World's Two Largest Democracies."

Garrett, Geoffrey. 1993. "The Politics of Structural Change Swedish Social Democracy and Thatcherism in Comparative Perspective." Comparative Political Studies 25(4): 521-47.

Geels, Frank W., and Johan Schot. 2007. "Typology of sociotechnical transition pathways." Research Policy 36 (3):399-417. doi: 10.1016/j.respol.2007.01.003.

Gobillon, Laurent, and Thierry Magnac. 2015. "Regional Policy Evaluation: Interactive Fixed Effects and Synthetic Controls." The Review of Economics and Statistics 98(3): 535-51.

Hake, Jürgen-Friedrich, Wolfgang Fischer, Sandra Venghaus, and Christoph Weckenbrock. 2015. "The German Energiewende - History and status quo." Energy 92:532-546. doi: 10.1016/j.energy.2015.04.027.

Hall, Peter A., and David Soskice, eds. 2001. Varieties of Capitalism. The Institutional Foundations of Comparative Advantage. Oxford: Oxford University Press.

Hays, Jude C., Sean D. Ehrlich, and Clint Peinhardt. 2005. "Government Spending and Public Support for Trade in the OECD: An Empirical Test of the Embedded Liberalism Thesis." International Organization 59(2): 473-94.

Helm, Dieter. 2004. Energy, the State, and the Market: British Energy Policy Since 1979. Oxford University Press.

Henisz, Witold J. 2002. “The Institutional Environment for Infrastructure Investment.” Industrial and Corporate Change 11(2): 355-89.

Hochstetler, Kathryn. 2020. Political Economies of Energy Transition: Wind and Solar Power in Brazil and Africa. Cambridge: Cambridge University Press.

IEA. 1974. Agreement on an International Energy Programme.

Ikenberry, G. John. 1986. "The Irony of State Strength: Comparative Responses to the Oil Shocks in the 1970s." International Organization 40 (1):105-137. 
Ikenberry, G. John. 1986. "The Irony of State Strength: Comparative Responses to the Oil Shocks in the 1970s." International Organization 40(1): 105-37.

Imai, Kosuke, and In Song Kim. 2020. "On the Use of Two-Way Fixed Effects Regression Models for Causal Inference with Panel Data." Political Analysis: 1-11.

Jacobs, Alan M. 2011. Governing for the Long Term: Democracy and the Politics of Investment. Cambridge: Cambridge University Press. http://ebooks.cambridge.org/ref/id/CBO9780511921766 (April 19, 2016).

Jacobsson, Staffan, and Volkmar Lauber. 2006. "The politics and policy of energy system transformation - explaining the German diffusion of renewable energy technology." Energy Policy 34 (3):256-276. doi: 10.1016/j.enpol.2004.08.029.

Johnson, Chalmers. 1982. MITI and the Japanese Miracle: The Growth of Industry Policy. Stanford, CA: Stanford University Press.

Katzenstein, Peter J. 1985. Small states in world markets: Industrial policy in Europe: Cornell University Press.

Kayser, Mark Andreas, and René Lindstädt. 2015. "A Cross-National Measure of Electoral Competitiveness." Political Analysis 23(2): 242-53.

Kennedy, David M. 1999. Freedom from fear: The American people in depression and war, 1929-1945: Oxford University Press.

Keohane, Robert O. 2014. "The Global Politics of Climate Change: Challenge for Political Science." PS: Political Science \& Politics 48 (01):19-26. doi: $10.1017 / \mathrm{s} 1049096514001541$.

Knotz, Carlo, and Johannes Lindvall. 2015. "Coalitions and Compensation: The Case of Unemployment Benefit Duration.” Comparative Political Studies 48(5): 586-615.

Kono, Daniel Y. 2011. "Insuring Free Trade: Unemployment Insurance and Trade Policy." Business and Politics 13(3): 1-29.

- 2019. "Compensating for the Climate: Unemployment Insurance and Climate Change Votes.” Political Studies. https://doi.org/10.1177/0032321719836066 (April 25, 2019).

Krieckhaus, Jonathan. 2002. "Reconceptualizing the developmental state: public savings and economic growth." World development 30 (10):1697-1712.

Lehmbruch, Gerhard. 1984. "Concertation and the Structure of Corporatist Networks." In Order and Conflict in Contemporary Capitalism, ed. John Goldthorpe. Oxford: Clarendon Press.

Lindvall, Johannes. 2017. Refom Capacity. Oxford: Oxford University Press.

Lipscy, Phillip Y. 2018. The Institutional Politics of Energy and Climate Change. Book Manuscript. Stanford University, Stanford CA.

Lipscy, Phillip Y. 2020. "COVID-19 and the Politics of Crisis." International Organization:130. doi: 10.1017/s0020818320000375.

Lipscy, Phillip Y., and Haillie Na-Kyung Lee. 2019. "The IMF As a Biased Global Insurance Mechanism: Asymmetrical Moral Hazard, Reserve Accumulation, and Financial Crises." International Organization 73(1): 35-64.

Lucas, Nigel. 1985. Western European Energy Policies: A Comparative Study of the Influence of Institutional Structure on Technical Change. Clarendon Press. 
Mahdavi, Paasha. 2020. Power Grab: Political Survival Through Extractive Resource Nationalization: Cambridge University Press.

Mallaburn, Peter S., and Nick Eyre. 2014. "Lessons from Energy Efficiency Policy and Programmesin the UK from 1973 to 2013.” Energy Efficiency 7(1): 23-41.

Martin, Cathie Jo, and Duane Swank. 2012. The Political Construction of Business Interests: Coordination, Growth, and Equality. New York: Cambridge University Press.

Matthews, Mary M. 2001. "Cleaning Up Their Acts: Shifts of Environment and Energy Policies in Pluralist and Corporatist States." Policy Studies Journal 29 (3):478-498.

Meckling, Jonas, and Jonas Nahm. 2018b. "The power of process: State capacity and climate policy." Governance. doi: 10.1111/gove.12338.

Mildenberger, Matto. 2020. Carbon Captured: How Business and Labor Control Climate Politics. Cambridge, MA: MIT Press.

Olson, Mancur. 1982. The Rise and Decline of Nations. New Haven, CT: Yale University Press.

Palier, Bruno. 1999. "Réformer la sécurité sociale: Les interventions gouvernementales en matière de protection sociale depuis 1945, la France en perspective comparative." Paris, Institut d'études politiques.

Parliament. 1974. "Sacrifices for Survival: Significant Redistribution of Income in Budget That Restrains Demand by $£ 200 \mathrm{~m}$." The Times.

Pearson, Professor Peter. 2012. "UK Energy Policy 1980-2010: A History and Lessons to Be Learnt.": 64.

Persson, Torsten, and Guido Tabellini. 1999. "The Size and Scope of Government:: Comparative Politics with Rational Politicians.” European Economic Review 43(4-6): 699-735.

Persson, Torsten, Gerard Roland, and Guido Tabellini. 2007. "Electoral Rules and Government Spending in Parliamentary Democracies.” Quarterly Journal of Political Science 2(2): $155-88$.

Pierson, Paul. 2004. Politics in time: History, institutions, and social analysis: Princeton University Press.

Powell, G. Bingham, and Guy D. Whitten. 1993. "A Cross-National Analysis of Economic Voting: Taking Account of the Political Context." American Journal of Political Science 37(2): 391-414.

Rabe, Barry G., Michael E. Kraft, and Sheldon Kamieniecki. 2018. Can We Price Carbon? Cambridge, MA: MIT Press.

Renn, Ortwin, and Jonathan Paul Marshall. 2016. "Coal, nuclear and renewable energy policies in Germany: From the 1950s to the "Energiewende"." Energy Policy. doi: 10.1016/j.enpol.2016.05.004.

Rickard, Stephanie J. 2015. "Compensating the Losers: An Examination of Congressional Votes on Trade Adjustment Assistance." International Interactions 41(1): 46-60.

Rodrik, D. 2014. "Green industrial policy." Oxford Review of Economic Policy 30 (3):469-491. doi: 10.1093/oxrep/gru025.

Rodrik, Dani. 1998. "Why Do More Open Economies Have Bigger Governments?” Journal of Political Economy 106(5): 997-1032. 
Rogowski, Ronald, and Mark Andreas Kayser. 2002. "Majoritarian Electoral Systems and Consumer Power: Price-Level Evidence from the OECD Countries." American Journal of Political Science 46(3): 526-39.

Roland, Gerard. 2002. "The Political Economy of Transition." Journal of economic Perspectives 16(1): 29-50.

Rosenbloom, Daniel, James Meadowcroft, and Benjamin Cashore. 2019. "Stability and climate policy? Harnessing insights on path dependence, policy feedback, and transition pathways." Energy Research \& Social Science 50:168-178. doi:

10.1016/j.erss.2018.12.009.

Ross, Michael L, Chad Hazlett, and Paasha Mahdavi. 2017. "Global progress and backsliding on gasoline taxes and subsidies." Nature Energy 2 (1):1-6.

Saich, Tony. 2010. Governance and politics of China: Macmillan International Higher Education.

Scheve, Kenneth, and David Stasavage. 2010. "The conscription of wealth: mass warfare and the demand for progressive taxation." International organization 64 (4):529-561.

Schmidt, Vivien A. 1996. From state to market?: the transformation of French business and government: Cambridge University Press.

Schmitt, Dieter. 1982. "West German Energy Policy." In After the Second Oil Crisis, edited by Wilfrid L. Kohl. Lexington, MA: LexingtonBooks.

Steinmo, Sven, Kathleen Thelen, and Frank Longstreth. 1992. Structuring politics: Historical individualism in comparative analysis. Cambridge: Cambridge University Press.

Steinmo, Sven. 1989. "Political Institutions and Tax Policy in the United States, Sweden, and Britain." World Politics 41 (500-535).

Stokes, Leah Cardamore. 2020. Short circuiting policy: Interest groups and the battle over clean energy and climate policy in the American States: Oxford University Press, USA.

Storchmann, Karl. 2005. "The rise and fall of German hard coal subsidies." Energy Policy 33 (11):1469-1492. doi: 10.1016/j.enpol.2004.01.006.

Tait, Alan A, and David R Morgan. 1980. "Gasoline taxation in selected OECD countries, 197079." Staff Papers 27 (2):349-379.

Trebilcock, M. J. 2014. Dealing with Losers: The Political Economy of Policy Transitions. Oxford University Press.

Vail, Mark. 2010. Recasting welfare capitalism: economic adjustment in contemporary France and Germany: Temple University Press.

Wade, Nicholas. 1980. "France's all-out nuclear program takes shape." Science;(United States) 209.

Wade, Robert. 1990. Governing the Market: Economic Theory and the Role of Government in East Asian Industrialization. Princeton: Princeton University Press.

Warren, Mark E., and Jane Mansbridge. 2016. "Deliberative Negotiation.” In Political Negotiation: A Handbook, eds. Jane Mansbridge and Cathie Jo Martin. Washington, D.C.: Brookings Institution Press.

Williams, Roger. 1980. The Nuclear Power Decisions: British Policies, 1953-78. Routledge. Woo-Cumings, Meredith, ed. 1999. The Developmental State. Ithaca, NY: Cornell University Press.

Xu, Yiqing. 2017. "Generalized Synthetic Control Method: Causal Inference with Interactive Fixed Effects Models.” Political Analysis 25(1): 57-76. 


\section{Supporting Information}

Table A1. Gasoline tax data sources

\begin{tabular}{|c|c|}
\hline Country & Source \\
\hline Australia & $\begin{array}{l}\text { James, Denis. 1996. “’Beer and Cigs Up!': A Recent History } \\
\text { of Excise in Australia.” Australia Parliamentary Research } \\
\text { Service, Background Paper No. } 5 \text { 1995-1996 }\end{array}$ \\
\hline Austria & $\begin{array}{l}\text { US Bureau of Mines, International Petroleum Annual; } \\
\text { International Energy Agency, Energy Prices and Taxes }\end{array}$ \\
\hline Belgium & $\begin{array}{l}\text { US Bureau of Mines, International Petroleum Annual; } \\
\text { International Energy Agency, Energy Prices and Taxes }\end{array}$ \\
\hline Canada & $\begin{array}{l}\text { US Bureau of Mines, International Petroleum Annual; } \\
\text { International Energy Agency, Energy Prices and Taxes }\end{array}$ \\
\hline Denmark & $\begin{array}{l}\text { US Bureau of Mines, International Petroleum Annual; } \\
\text { Statistics Denmark, Moms og energiafgifter }\end{array}$ \\
\hline Finland & $\begin{array}{l}\text { US Bureau of Mines, International Petroleum Annual; } \\
\text { International Energy Agency, Energy Prices and Taxes }\end{array}$ \\
\hline France & $\begin{array}{l}\text { US Bureau of Mines, International Petroleum Annual; } \\
\text { International Energy Agency, Energy Prices and Taxes }\end{array}$ \\
\hline Germany & $\begin{array}{l}\text { German Federal Ministry of Finance, Entwicklung der } \\
\text { Energie- (vormals Mineralöl-) und Stromsteuersätze in der } \\
\text { Bundesrepublik Deutschland }\end{array}$ \\
\hline Ireland & $\begin{array}{l}\text { US Bureau of Mines, International Petroleum Annual; } \\
\text { Department of Finance, MOT Rates }\end{array}$ \\
\hline Italy & $\begin{array}{l}\text { US Bureau of Mines, International Petroleum Annual; } \\
\text { International Energy Agency, Energy Prices and Taxes }\end{array}$ \\
\hline Japan & Ministry of Internal Affairs and Communications \\
\hline Netherlands & $\begin{array}{l}\text { US Bureau of Mines, International Petroleum Annual; } \\
\text { International Energy Agency, Energy Prices and Taxes }\end{array}$ \\
\hline New Zealand & $\begin{array}{l}\text { Ministry of Business, Innovation and Employment, Quarterly } \\
\text { Average Nominal Tax Rates }\end{array}$ \\
\hline Norway & $\begin{array}{l}\text { US Bureau of Mines, International Petroleum Annual; } \\
\text { International Energy Agency, Energy Prices and Taxes }\end{array}$ \\
\hline Sweden & Swedish Petroleum and Biofuels Institute (SPBI) \\
\hline Switzerland & $\begin{array}{l}\text { US Bureau of Mines, International Petroleum Annual; } \\
\text { International Energy Agency, Energy Prices and Taxes }\end{array}$ \\
\hline UK & Institute of Petroleum, UK Petrol Prices (1902-1994) \\
\hline US & $\begin{array}{l}\text { US Federal Highway Administration, Highway Finance } \\
\text { Statistics }\end{array}$ \\
\hline
\end{tabular}


Table A2. OLS Regressions with Two-Way Fixed Effects: Country-clustered Standard Errors

\begin{tabular}{|c|c|c|c|c|c|c|}
\hline & $\begin{array}{c}\text { (1) } \\
\text { Electricity } \\
\text { generation } \\
\text { from oil } \\
(\% \text { of total })\end{array}$ & $\begin{array}{l}\text { (1) } \\
\text { Electricity } \\
\text { generation } \\
\text { from oil } \\
(\% \text { of total })\end{array}$ & $\begin{array}{c}(1) \\
\text { Electricity } \\
\text { generation } \\
\text { from oil } \\
(\% \text { of total })\end{array}$ & $\begin{array}{c}(2) \\
\text { Gasoline } \\
\text { tax rate } \\
\text { (USD/liter) }\end{array}$ & $\begin{array}{c}(2) \\
\text { Gasoline } \\
\text { tax rate } \\
\text { (USD/liter) }\end{array}$ & $\begin{array}{c}(2) \\
\text { Gasoline } \\
\text { tax rate } \\
\text { (USD/liter) }\end{array}$ \\
\hline Oil price shock (1973) & $\begin{array}{l}-2.71 \\
(2.37)\end{array}$ & $\begin{array}{c}1.67 \\
(6.95)\end{array}$ & $\begin{array}{c}1.71 \\
(7.02)\end{array}$ & $\begin{array}{c}0.05^{*} \\
(0.01)\end{array}$ & $\begin{array}{c}0.15^{*} \\
(0.05)\end{array}$ & $\begin{array}{c}0.15^{*} \\
(0.05)\end{array}$ \\
\hline $\begin{array}{l}\text { Oil price shock (1973)* } \\
\text { Supply-side institutions }\end{array}$ & $\begin{array}{l}-8.37^{*} \\
(2.95)\end{array}$ & $\begin{array}{l}-9.62^{*} \\
(3.27)\end{array}$ & $\begin{array}{l}-9.09^{*} \\
(3.48)\end{array}$ & & & \\
\hline $\begin{array}{l}\text { Oil price shock }(1973)^{*} \\
\text { Demand-side institutions }\end{array}$ & & & & $\begin{array}{l}0.08^{*} \\
(0.01)\end{array}$ & $\begin{array}{l}0.09^{*} \\
(0.01)\end{array}$ & $\begin{array}{c}0.09^{*} \\
(0.01)\end{array}$ \\
\hline $\begin{array}{l}\text { Economic Control Variables } \\
\text { Political Control Variables } \\
\text { Country FE } \\
\text { Year FE } \\
\text { Countries } \\
N\end{array}$ & $\begin{array}{l}\text { No } \\
\text { No } \\
\text { Yes } \\
\text { Yes } \\
18 \\
378\end{array}$ & $\begin{array}{l}\text { Yes } \\
\text { No } \\
\text { Yes } \\
\text { Yes } \\
18 \\
378\end{array}$ & $\begin{array}{l}\text { Yes } \\
\text { Yes } \\
\text { Yes } \\
\text { Yes } \\
18 \\
378\end{array}$ & $\begin{array}{l}\text { No } \\
\text { No } \\
\text { Yes } \\
\text { Yes } \\
18 \\
376\end{array}$ & $\begin{array}{l}\text { Yes } \\
\text { No } \\
\text { Yes } \\
\text { Yes } \\
18 \\
376\end{array}$ & $\begin{array}{l}\text { Yes } \\
\text { Yes } \\
\text { Yes } \\
\text { Yes } \\
18 \\
376\end{array}$ \\
\hline
\end{tabular}

Note: Country-clustered standard errors in parentheses. ${ }^{*} p<0.05$ 
Table A3. OLS Regressions with Two-Way Fixed Effects: Lagged Dependent Variable

\begin{tabular}{|c|c|c|c|c|c|c|}
\hline & $\begin{array}{c}(1) \\
\text { Electricity } \\
\text { generation } \\
\text { from oil } \\
(\% \text { of total }) \\
\end{array}$ & $\begin{array}{c}(1) \\
\text { Electricity } \\
\text { generation } \\
\text { from oil } \\
(\% \text { of total }) \\
\end{array}$ & $\begin{array}{c}(1) \\
\text { Electricity } \\
\text { generation } \\
\text { from oil } \\
(\% \text { of total }) \\
\end{array}$ & $\begin{array}{c}(2) \\
\text { Gasoline } \\
\text { tax rate } \\
\text { (USD/liter) }\end{array}$ & $\begin{array}{c}(2) \\
\text { Gasoline } \\
\text { tax rate } \\
\text { (USD/liter) }\end{array}$ & $\begin{array}{c}(2) \\
\text { Gasoline } \\
\text { tax rate } \\
\text { (USD/liter) }\end{array}$ \\
\hline $\begin{array}{l}\text { Lagged Dependent } \\
\text { Variable }\end{array}$ & $\begin{aligned} 0.88^{*} \\
(0.03)\end{aligned}$ & $\begin{array}{l}0.87 * \\
(0.03)\end{array}$ & $\begin{array}{r}0.87^{*} \\
(0.03)\end{array}$ & $\begin{array}{r}0.73 * \\
(0.04)\end{array}$ & $\begin{array}{l}0.71 * \\
(0.04)\end{array}$ & $\begin{array}{l}0.70^{*} \\
(0.04)\end{array}$ \\
\hline Oil price shock (1973) & $\begin{array}{l}-0.58 \\
(1.55)\end{array}$ & $\begin{array}{c}2.60 \\
(3.21)\end{array}$ & $\begin{array}{c}2.42 \\
(3.19)\end{array}$ & $\begin{array}{c}0.01 \\
(0.01)\end{array}$ & $\begin{array}{c}0.06^{*} \\
(0.02)\end{array}$ & $\begin{array}{l}0.06^{*} \\
(0.02)\end{array}$ \\
\hline $\begin{array}{l}\text { Oil price shock }(1973)^{*} \\
\text { Supply-side institutions }\end{array}$ & $\begin{array}{l}-3.01^{*} \\
(0.97)\end{array}$ & $\begin{array}{l}-4.01^{*} \\
(1.08)\end{array}$ & $\begin{array}{l}-3.73^{*} \\
(1.08)\end{array}$ & & & \\
\hline $\begin{array}{l}\text { Oil price shock }(1973)^{*} \\
\text { Demand-side institutions }\end{array}$ & & & & $\begin{array}{c}0.023^{*} \\
(0.005)\end{array}$ & $\begin{array}{c}0.028^{*} \\
(0.006)\end{array}$ & $\begin{array}{c}0.030^{*} \\
(0.006)\end{array}$ \\
\hline $\begin{array}{l}\text { Economic Control Variables } \\
\text { Political Control Variables } \\
\text { Country FE } \\
\text { Year FE } \\
\text { Countries } \\
N\end{array}$ & $\begin{array}{l}\text { No } \\
\text { No } \\
\text { Yes } \\
\text { Yes } \\
18 \\
378\end{array}$ & $\begin{array}{l}\text { Yes } \\
\text { No } \\
\text { Yes } \\
\text { Yes } \\
18 \\
378\end{array}$ & $\begin{array}{l}\text { Yes } \\
\text { Yes } \\
\text { Yes } \\
\text { Yes } \\
18 \\
378\end{array}$ & $\begin{array}{l}\text { No } \\
\text { No } \\
\text { Yes } \\
\text { Yes } \\
18 \\
375\end{array}$ & $\begin{array}{l}\text { Yes } \\
\text { No } \\
\text { Yes } \\
\text { Yes } \\
18 \\
375 \\
\end{array}$ & $\begin{array}{l}\text { Yes } \\
\text { Yes } \\
\text { Yes } \\
\text { Yes } \\
18 \\
375\end{array}$ \\
\hline
\end{tabular}

Note: Standard errors in parentheses. ${ }^{*} p<0.05$ 
Table A4. OLS Regressions with Two-Way Fixed Effects: Heterogenous treatment effects

\begin{tabular}{|c|c|c|c|c|c|c|}
\hline & $\begin{array}{c}\text { (1) } \\
\text { Electricity } \\
\text { generation } \\
\text { from oil } \\
(\% \text { of total })\end{array}$ & $\begin{array}{c}(1) \\
\text { Electricity } \\
\text { generation } \\
\text { from oil } \\
(\% \text { of total })\end{array}$ & $\begin{array}{c}(1) \\
\text { Electricity } \\
\text { generation } \\
\text { from oil } \\
(\% \text { of total })\end{array}$ & $\begin{array}{c}(2) \\
\text { Gasoline } \\
\text { tax rate } \\
\text { (USD/liter) }\end{array}$ & $\begin{array}{c}(2) \\
\text { Gasoline } \\
\text { tax rate } \\
\text { (USD/liter) }\end{array}$ & $\begin{array}{c}\text { (2) } \\
\text { Gasoline } \\
\text { tax rate } \\
\text { (USD/liter) }\end{array}$ \\
\hline Oil dependence (1972) & $\begin{array}{c}4.48 \\
(6.25)\end{array}$ & $\begin{array}{c}0.94 \\
(5.38)\end{array}$ & $\begin{array}{c}0.87 \\
(5.27)\end{array}$ & $\begin{array}{c}0.06 \\
(0.02)\end{array}$ & $\begin{array}{c}0.06^{*} \\
(0.02)\end{array}$ & $\begin{array}{c}0.06^{*} \\
(0.02)\end{array}$ \\
\hline $\begin{array}{l}\text { Oil dependence }(1972) * \\
\text { Supply-side institutions }\end{array}$ & $\begin{array}{l}-15.80^{*} \\
(5.55)\end{array}$ & $\begin{array}{r}-14.15^{*} \\
(6.02)\end{array}$ & $\begin{array}{l}-13.67^{*} \\
(6.08)\end{array}$ & & & \\
\hline $\begin{array}{l}\text { Oil dependence }(1972) * \\
\text { Demand-side institutions }\end{array}$ & & & & $\begin{array}{r}0.071^{*} \\
(0.012)\end{array}$ & $\begin{array}{r}0.077^{*} \\
(0.018)\end{array}$ & $\begin{array}{c}0.076^{*} \\
(0.017)\end{array}$ \\
\hline $\begin{array}{l}\text { Economic Control Variables } \\
\text { Political Control Variables } \\
\text { Country FE } \\
\text { Year FE } \\
\text { Countries } \\
N\end{array}$ & $\begin{array}{l}\text { No } \\
\text { No } \\
\text { Yes } \\
\text { Yes } \\
18 \\
378\end{array}$ & $\begin{array}{l}\text { Yes } \\
\text { No } \\
\text { Yes } \\
\text { Yes } \\
18 \\
378\end{array}$ & $\begin{array}{l}\text { Yes } \\
\text { Yes } \\
\text { Yes } \\
\text { Yes } \\
18 \\
378\end{array}$ & $\begin{array}{l}\text { No } \\
\text { No } \\
\text { Yes } \\
\text { Yes } \\
18 \\
376\end{array}$ & $\begin{array}{l}\text { Yes } \\
\text { No } \\
\text { Yes } \\
\text { Yes } \\
18 \\
376\end{array}$ & $\begin{array}{l}\text { Yes } \\
\text { Yes } \\
\text { Yes } \\
\text { Yes } \\
18 \\
376\end{array}$ \\
\hline
\end{tabular}

Note: Oil dependence (1972) is net oil imports as a percentage of the Total Primary Energy Supply (TPES) in 1972. Country-clustered standard errors in parentheses. ${ }^{*} p<0.05$. 
Figure A1. Estimated Average Treatment Effect: Supply-Side Institutions and Oil Share of Electricity Production (Generalized Synthetic Control)

\section{Estimated ATT}

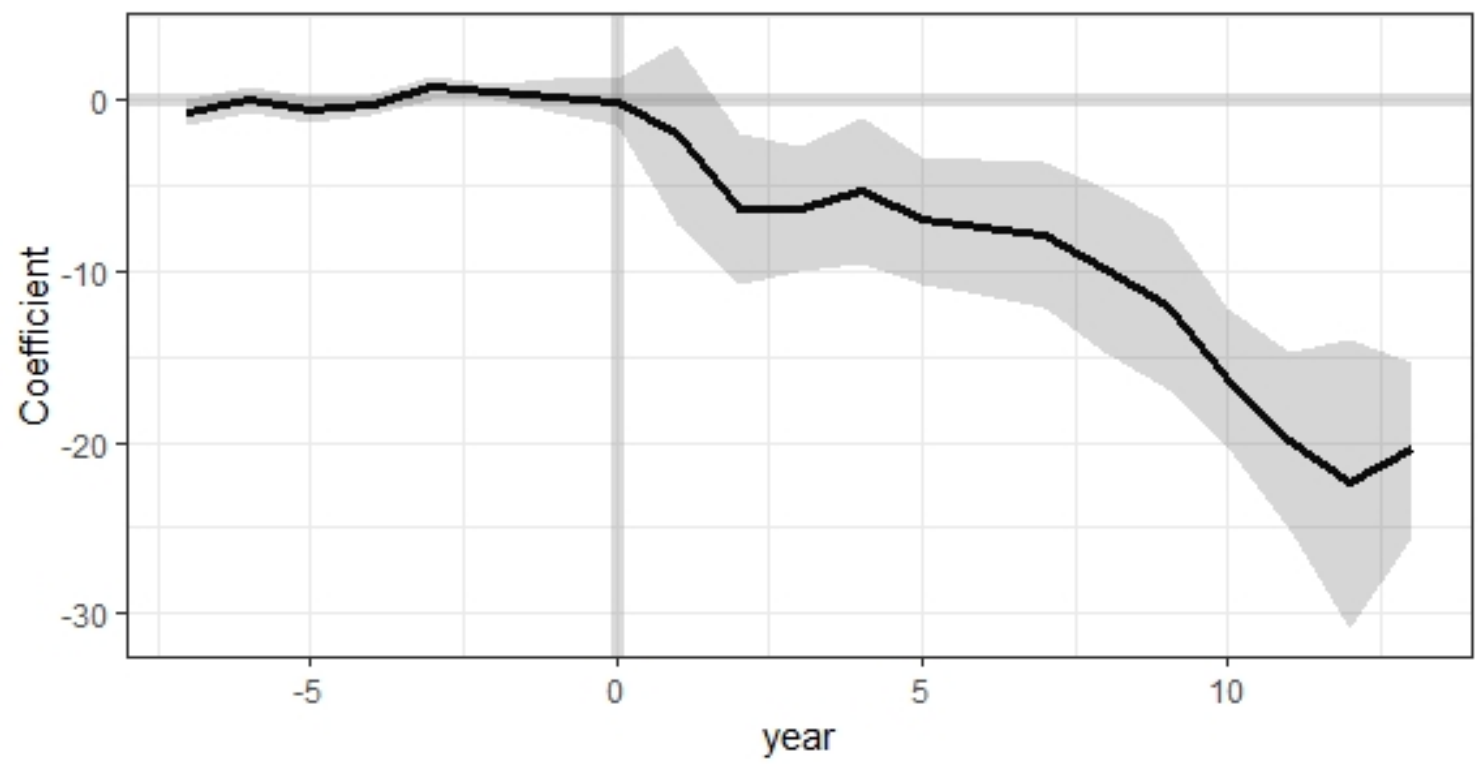

Note: The figure presents estimated average treatment effects of supply-side institutions on oil share of electricity production. The figure shows that there is a statistically meaningful difference between the trajectory of countries with supply-side institutions and the counterfactual after the oil shock. Uncertainty estimates are based on parametric bootstrap procedure and EM method of Gobillon and Magnac 2016. 
Figure A2. Estimated Average Treatment Effect: Demand-Side Institutions and Gasoline Taxes (Generalized Synthetic Control)

\section{Estimated ATT}

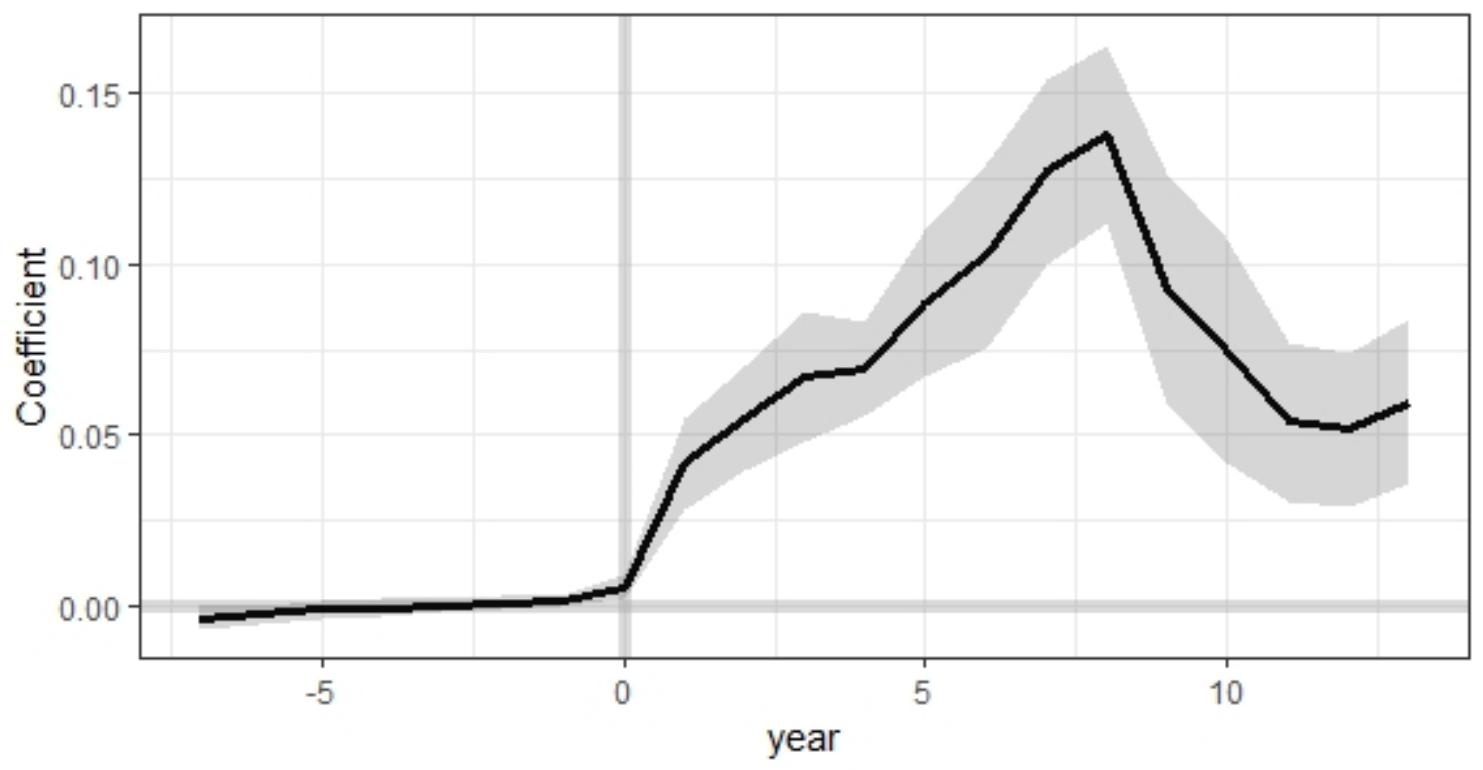

Note: The figure presents estimated average treatment effects of demand-side institutions on gasoline taxes. The figure shows that there is a statistically meaningful difference between the trajectory of countries with demand-side institutions and the counterfactual after the oil shock. Uncertainty estimates are based on parametric bootstrap procedure and EM method of Gobillon and Magnac 2016. 
Figure A3. The Effect of Supply- and Demand-Side Institutions on Total Oil Consumption (Generalized Synthetic Control)

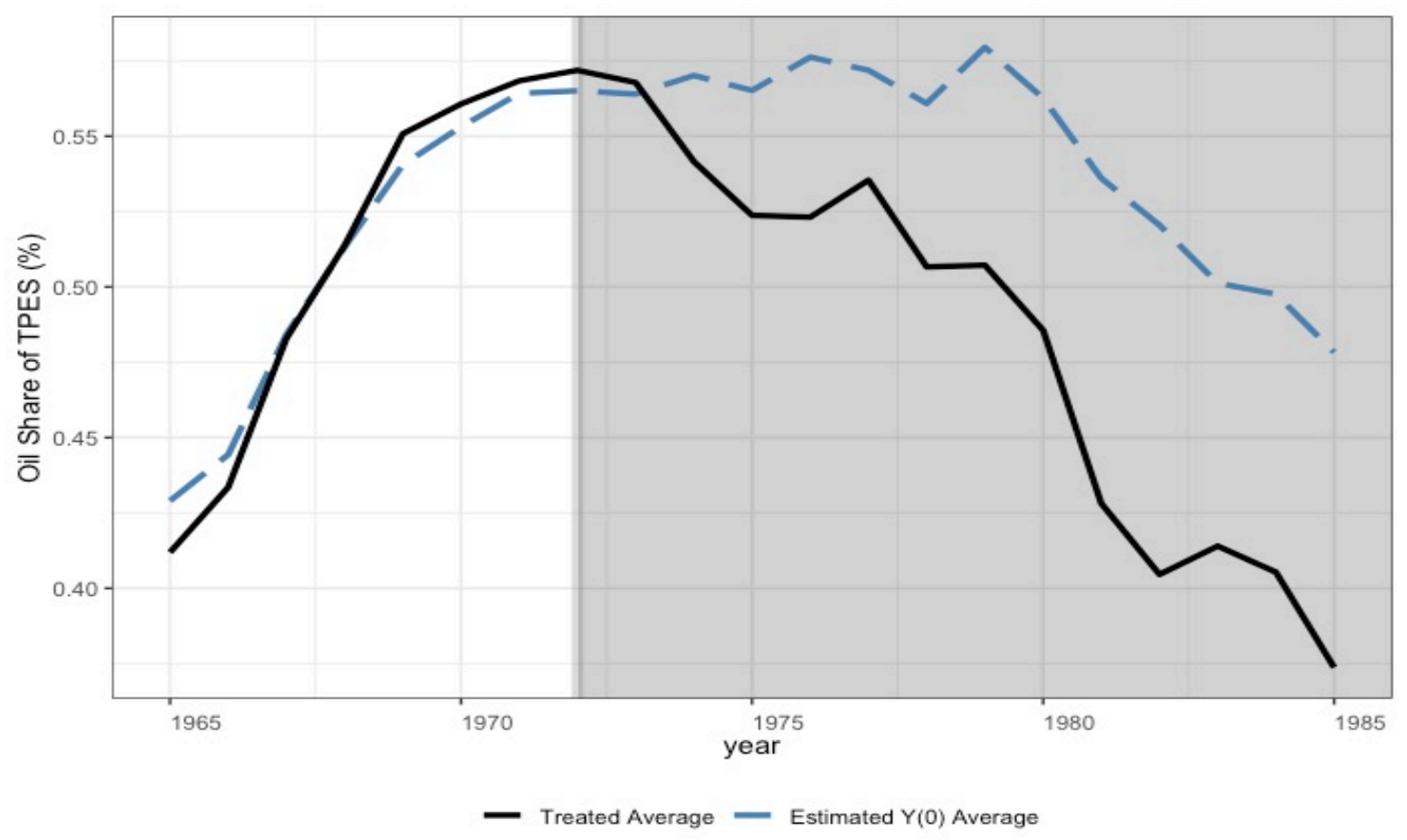

Note: The oil share of TPES is total oil consumption across all sectors as a percent of the total primary energy supply (TPES). Countries with both supply- and demand-side institutions are coded as 1 . Countries with neither institution are coded 0 . 
Figure A4. Estimated Average Treatment Effect: Supply- and Demand-Side Institutions and Total Oil Consumption (Generalized Synthetic Control)

\section{Estimated ATT}

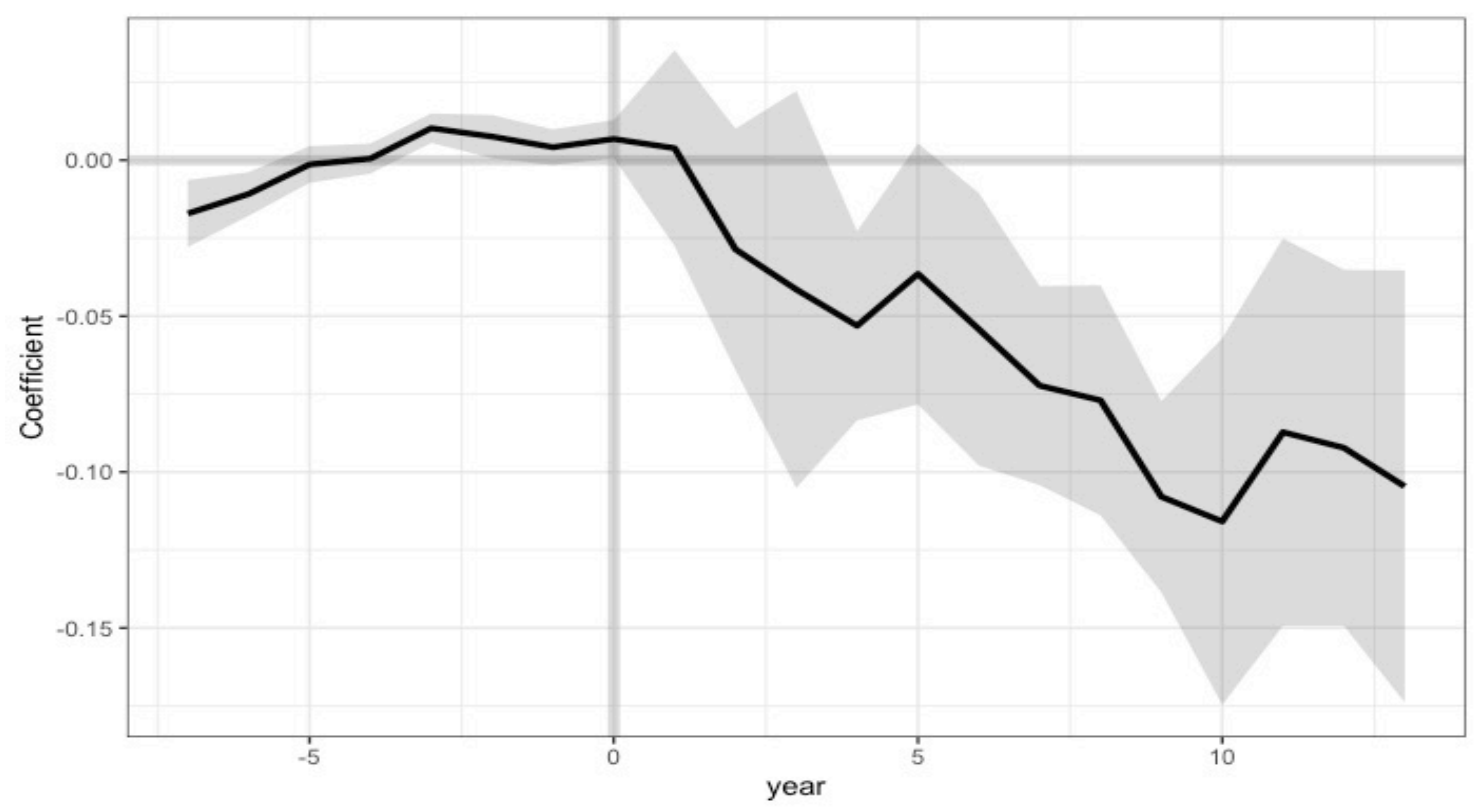

Note: The figure presents estimated average treatment effects of combined supply- and demand-side institutions on the oil share of the total primary energy supply (TPES). The figure shows that there is a statistically meaningful difference between the trajectory of countries with supply- and demand-side institutions and the counterfactual after the oil shock. Uncertainty estimates are based on parametric bootstrap procedure and EM method of Gobillon and Magnac 2016. 


\section{Additional information on the discourse network analysis: data gathering and analysis of energy policy discourses in UK and Germany}

We created a data set about historical energy policy discourses between 1970 and 1985 in Germany and the United Kingdom in four steps (data gathering in UK: June - August 2019, G: October 2019 - June 2020).

\section{Newspaper selection}

First, we selected daily newspapers with comparably high coverage and a politically moderate orientation. For the UK, we selected The Times, which is available as digital full-text archives going back to the 1970s through this website: https://gdc.galegroup.com/gdc/artemis?p=TTDA\&u=unibern

For Germany, we selected the Frankfurter Allgemeine Zeitung (FAZ), which was accessible to us from the library Zentralbibliothek in Zurich.

\section{Sampling of articles}

Second, we sampled articles for the timeframe 1970-1985 based on a number of keywords and operators (UK: energy policy, AND Britian, NOT EEC, OR oil crisis, OR nuclear, OR efficiency, OR electricity, OR alternatives, OR wave energy, OR fuel; Germany: Oil crisis OR energy* OR *energy AND Germany OR oil OR wind energy OR solar panel OR water energy OR "alternative energy" OR nuclear energy OR nuclear electricity OR efficiency OR coal OR electricity OR petrol NOT lead NOT GDR).

The above-defined criteria resulted in a total of 79'918 articles for The Times and 29'974 articles for the FAZ. Articles were sorted by relevance, i.e., a ranking option that websites provide to determine how closely each item focuses on the defined search terms. Two independent coders then selected articles reading the headlines and the main keywords contained in the article based on case-study knowledge from a thorough literature review about the UK's and Germany's energy policies. Coders stopped sampling after 500 selected articles. To ensure sufficient coverage for each year, we conducted a second round of sampling articles specifically for those years that were less well covered (The Times: 1970-1972, FAZ: 1976, 1982-1983). Our final corpus consists of 559 articles for The Times and 520 for the FAZ for the 1970-1985 period; and of 432 and 436 articles for the 1973-1985 post-oil crisis period. 


\section{Coding Procedure}

Third, coders read all articles and manually encoded their contents in the Discourse Network Analyzer software (available on Github https://github.com/leifeld/dna/; UK: version dna-2.0beta24.jar with rDNA 2.1.16 from February 17, 2019; G: version dna-2.0-beta25.jar with rDNA 2.1.18 from August 09, 2019) based on a systematic codebook. After a first round of coding, we made plots of the coding results in order to get an overview of the data, spot inconsistencies and discuss coding questions. Coders then performed a second round of coding to clean the data, i.e., correct mistakes and ensure consistency in coding.

\section{Intercoder reliability}

Fourth, two independent coders worked on the same 10 articles whereby the first coder highlighted coded sentences for the second coder (without indicating which codes had been used). The second coder then coded those highlighted sentences. Thereby, we achieved a $69 \%$ of intercoder reliability for The Times and 50\% for the FAZ. Reliability here means that three coding elements are congruent: 1) coding the same actor, 2) choosing the same code among 32 different codes (e.g., diverse supply and demand side policies), and 3) using the same qualifier, i.e., whether or not the actor supported or rejected a policy.

\section{Codes and analysis}

We coded actors, their organizational type (e.g., government, ministry, parliament, coal, etc.), and their statements regarding responses to the oil shock as reported in the newspapers. Statements refer to three policy goals: energy security, energy costs and environment. More precisely, we used the code for 'energy security' when actors stated the importance of being energetically independent or when their goal was the security of energy supply. We applied the code for 'energy costs' every time actors developed an economic reasoning to explain a certain policy preference, e.g., by comparing the low cost of an energy option to one which is more expensive. We used the code for 'environment' when actors expressed environmental or climate concerns (e.g., pollution from coal mines and nuclear reactors). For the German case, this code also included the fear of security problems of nuclear power plants and health concerns of technologies, e.g., nuclear radiation.

For a graphical presentation of the data in a radar chart, we used the fmsb package in RStudio (Version 1.1.463). For each country, we calculated the ratio (in percentages) between the number of pro-statements for each goal (energy security, costs, environment) and the total number of prostatements reported after the oil crisis (cutoff date: 01.01.1973). 
Furthermore, we coded reports about physical meetings on energy policy and the actors participating in each meeting. We focus on meetings between government, different energy industry actors and utilities. The government group consists of actors coded as government, ministries, parliament and governmental research. The five different energy industry groups consist of actors representing the interests of nuclear energy, alternative energy, coal, oil and gas industries and their labor. In this paper, we concentrate on meetings held between losers (oil and utilities) and government. 